\title{
The Leptophlebiidae : Atalophlebiinae of New Caledonia (Ephemeroptera). Part VII : Systematics
}

\author{
W.L. Peters \\ J.G. Peters 1
}

Keywords : Ephemeroptera, taxonomy, New Caledonia, freshwaters.

The seventh in a series on the Leptophlebiidae (Ephemeroptera) of New Caledonia, this papers treats three new genera (Paraluma, Oumas, and Amoa) and 12 new species. For Paraluma gen.n., the type species $P$. cancellata sp.n., P. triangularis sp.n., $P$. gilva sp.n. and $P$. minuta sp.n. are described from male and female imagos and nymphs, $P$. pulla sp.n. from male imagos and nymphs, and $P$. maculata sp.n. from male and female imagos. For Amoa gen.n., the type species $A$. fronini sp.n., $A$. subsolana sp.n. and A. orthogonia sp.n. are described from male and female imagos and nymphs, A. cressonensis sp.n. from nymphs only and $A$. hebes sp.n. from the male imago only. Oumas orbis gen.n. sp.n. is described from male and female imagos and nymphs.

\section{Les Leptophlebiidae Atalophlebiinae de Nouvelle-Calédonie (Ephemeroptera). $7^{\mathrm{e}}$ partie : Systématique}

Mots-clés : Ephemeroptera, taxonomie, Nouvelle-Calédonie, eaux douces.

Septième d'une série de publications sur les Leptophlebiidae (Ephemeroptera) de Nouvelle-Calédonie, la présente contribution traite de trois genres nouveaux (Paraluma, Oumas et Amoa) et de 12 espèces nouvelles. Pour Paraluma $\mathbf{n}$. gen., l'espèce-type $P$. cancellata n. sp., P. triangularis n. sp., $P$. gilva sp. n. and P. minuta n. sp. sont décrites à partir d'imagos mâles et femelles et de larves, $P$. pulla à partir d'imagos mâles et de larves, et $P$. maculata $\mathrm{n}$. sp. à partir d'imagos mâles et femelles. Pour Amoa n. gen., l'espèce-type $A$. frontoni $\mathrm{n}$. sp., A. subsolana $\mathrm{n}$. sp., A. orthogonia $\mathrm{n}$. sp. sont décrites à partir d'imagos mâles et femelles et de larves, $A$. cressonensis $\mathbf{n}$. sp. à partir de larves seulement et $A$. hebes à partir d'une imago mâle seule. Oumas orbis $\mathbf{n}$. gen. n. sp. est décrite à partir d'imagos mâles et femelles et de larves.

\section{Introduction}

This paper is the seventh in a series on the systematics, phylogeny, and biogeography of the Leptophlebiidae of New Caledonia, all of which belong to the subfamily Atalophlebiinae. Part I of this series lists all localities (Peters et al. 1978). Other works on systematics are Peters \& Peters $(1980,1981 \mathrm{a}, 1981 \mathrm{~b})$ and Peters et al. $(1990,1994)$.

In this paper we describe three new genera which

1. Entomology, Orr Drive, Florida A\&M University, Tallahassee, FL 32307, USA. share the following characters : nymphal gills long and thin with unpigmented lamellae, nymphal mouthparts with only dorsal spines on the third segment of the labial palpi and smoothly curved mandibles, and female imagos with a broad seventh sternum. The relationships of these genera with each other are not clear, and there are few clear synapomorphies with genera from New Zealand (Towns \& Peters 1996).

Methods are discussed in previous sections (Peters et al. 1978). As clarified in Peters et al. (1994), body length is measured from the anterior margin of the prothorax to the posterior margin of tergum 10, and "mature nymph" refers to nymphs with developed wing pads, but not necessarily last instar nymphs. In des- 
criptions of forelegs of male imagos, all successive segments are compared with the tibia and expressed as a ratio (measurement of tibia is given in parentheses) and in figures of the labium of the nymph, the venter is figured on the right and the dorsum on the left.

Field work for this study was supported by the National Geographic Society, Washington, D.C., and some laboratory research was supported by a research program (FLAX 79009) of the Scientific and Educational Administration, CSREES, United States Department of Agriculture.

\section{Paraluma, new genus}

(Figs. 1-9, 23-26, 32, 35-40, 46-53, 57-61, 68-76, 94, 98-108, 124-126, 135-141)

\section{Imago}

Length of $\sigma^{\text {" : }}$ : body $3.0-6.8 \mathrm{~mm}$; fore wings $3.6-6.5$ $\mathrm{mm}$. Length of $\%$ : body $3.2-6.0 \mathrm{~mm}$; fore wings 3.67.5. $\mathrm{mm}$. Eyes of $\sigma^{7}$ separated on meson of head by a distance 1-1/2 times width of median ocellus to twice width of a lateral ocellus, dorsally upper portion oblong, upper portion on short stalk, lower portion a little more than $1 / 2$ length of upper portion (Fig. 23$26)$; eyes of $q$ separated on meson of head by a distance 3-5 times maximum width of an eye. Wings (Fig.1-9) : maximum width of fore wings $1 / 3$ to a little more than $1 / 3$ maximum length ; vein Rs of fore wings forked $1 / 5$ to a little more than $1 / 4$ of distance from base to margin ; vein MA forked about $1 / 2$ of distance from base to margin, fork symmetrical ; vein $\mathrm{MP}_{2}$ attached at base to veins $\mathrm{MP}_{1}$ and $\mathrm{CuA}$ with a cross vein (Fig. 1,7), attachment of vein $\mathrm{MP}_{2}$ to $\mathrm{MP}_{1}$ a little less than $1 / 3$ to $1 / 3$ of distance from base to margin, base of vein $\mathrm{MP}_{2}$ equidistant between veins $\mathrm{MP}_{1}$ and $\mathrm{CuA}$; vein $\mathrm{ICu}_{1}$ attached to veins $\mathrm{CuA}$ and $\mathrm{CuP}$ with a cross vein, remainder of $\mathrm{CuA}$ area as in Fig. 1, 7; cross veins few. Costal projection of hind wings well developed, rounded (Fig. 2-6, 8-9), apex located $1 / 2$ distance from base ; apex of wings acute, rounded ; cross veins few. Legs : ratios of segments in $0^{7}$ fore legs, $0.55-0.60$ : $1.00(2.0-2.5 \mathrm{~mm}): 0.04-0.05: 0.40: 0.35-0.36: 0.25$ $0.28: 0.12-0.15$. Claws of a pair dissimilar, one apically hooked (Fig. 32), other obtuse, pad-like. Male genitalia (Fig. 35-40) : segment 2 of forceps equal to a little longer in length than segment 3 , segment 2 of forceps $1 / 6$ to $1 / 5$ length of segment 1 ; base of forceps broad, its inner margin forming an angular bend near middle of forceps to inner margin smoothly tapered apically ; length of styliger plate along median line $1 / 4$ to a little more than 1/3 maximum width, apex shallowly cleft to smooth; penes fused except at apex, api- cal cleft V-shaped (Fig. 35, 38) to concave (Fig. 37), penes broad except broader near base, apex of each penis lobe acute laterally (Fig. 35-38) to rounded apically (Fig. 40), a broad ventral spine or flap near apex of each penis lobe. Ninth sternum of $\%$ entire apically (Fig. 53) ; sternum 7 broadly rounded (Fig. 57-61) (see discussion). Terminal filament a little longer than cerci.

\section{Mature Nymph}

Head prognathous. Antennae 1-1/2 to 2 times maximum length of head. Mouthparts (Fig. 98-108, 124126) : dorsal hair on labrum as in Fig. 98 ; submedian to subanterior areas of hair ventrally ; anteromedian emargination deeply cleft with 4-5 denticles on ventral surface (Fig. 99-105). Clypeus as in Fig. 98. Left mandible as in Fig. 107. Lingua of hypopharynx with well developed lateral processes and paired, submedian, internal longitudinal row of long hair on dorsum, anterior margin cleft, apex of submedian lobes with a rakelike process ; superlinguae as in Fig.126, with a row of hair along anterior margin, lateral margins blunt. Segment 2 of maxillary palpi equal to 1-1/4 length of segment 1 ; segment 3 of palpi $3 / 4$ to a little more than $4 / 5$ length of segment 2 , triangular ; a V-shaped ridge near the ventral, inner anterolateral margin of maxillae ; hair on maxillae as in Fig. 108. Labium as in Fig. 124 ; segment 2 of palpi a little shorter to a little longer than length of segment 1 ; segment 3 of palpi $2 / 3$ to $3 / 4$ length of segment 2, triangular; paraglossae ventral to glossae. Sparse, short, fine hair on anterolateral corners of pronotum, and sparse, long hair on dorsum of head and body. Legs (Fig. 135-137) : maximum width of tibiae a little greater than maximum width of tarsi, tibiae in cross section subtriangular ; outer margin of femora indented along apical half so tibiae can draw partially into femora (Fig. 135), apex of claws hooked and narrow, basal 3 denticles broad, progressively larger apically (Fig. 137), remaining denticles thin and progressively larger apically. Gills (Fig. 138) : gills on segments 1-7 alike; gills deeply forked and 2 portions of lamellae overlap on dorsal surface ; each portion long, narrow, smoothly tapered to apex ; main trunk of tracheae forked near base of gills and each branch along median line of each portion of lamellae, main trunk darkly pigmented, membrane of lamellae translucent. Posterolateral spines on abdominal segments 3 to 6-9, spines progressively larger posteriorly, apex of posterolateral spines on segment 9 indented and giving appearance of large double spines (Fig. 139). Terminal filament a little longer than cerci.

Etymology. par, L., meaning two ; luma, L., f., meaning thorn. Feminine.

Type species. Paraluma cancellata, new species. 

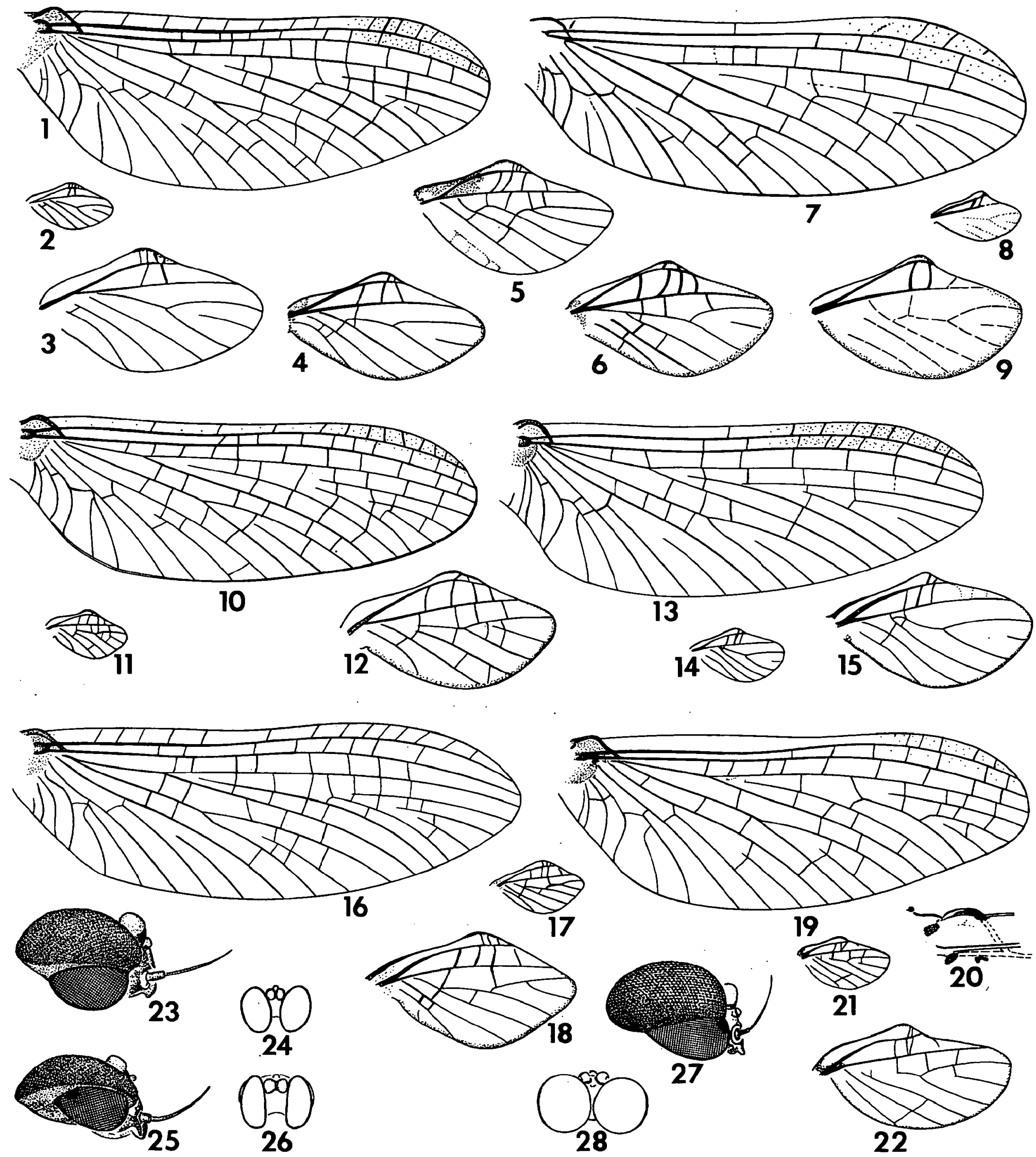

Figs. 1-22. male imago. 1-3, Paraluma cancellata ; 4, 23-24, P. triangularis ; 5, 25-26, P. pulla ; 6, P. minuta ; 7-9, P. maculata ; 10-12, 27-28, Oumas orbis ; 13-15, Amoa fronini ; 16-18, A. hebes ; 19-22, A. orthogonia. Fore wings $(1,7,10,13,16,19)$, ventral detail of costal brace $(20)$, hind wing to scale $(2,8,11,14,21)$ and enlarged $(3-6,9,12,15,18,22)$. Lateral $(23,25,27)$ and dorsal $(24,26,28)$ views of eyes.

Figs 1-28. imagos mâles. 

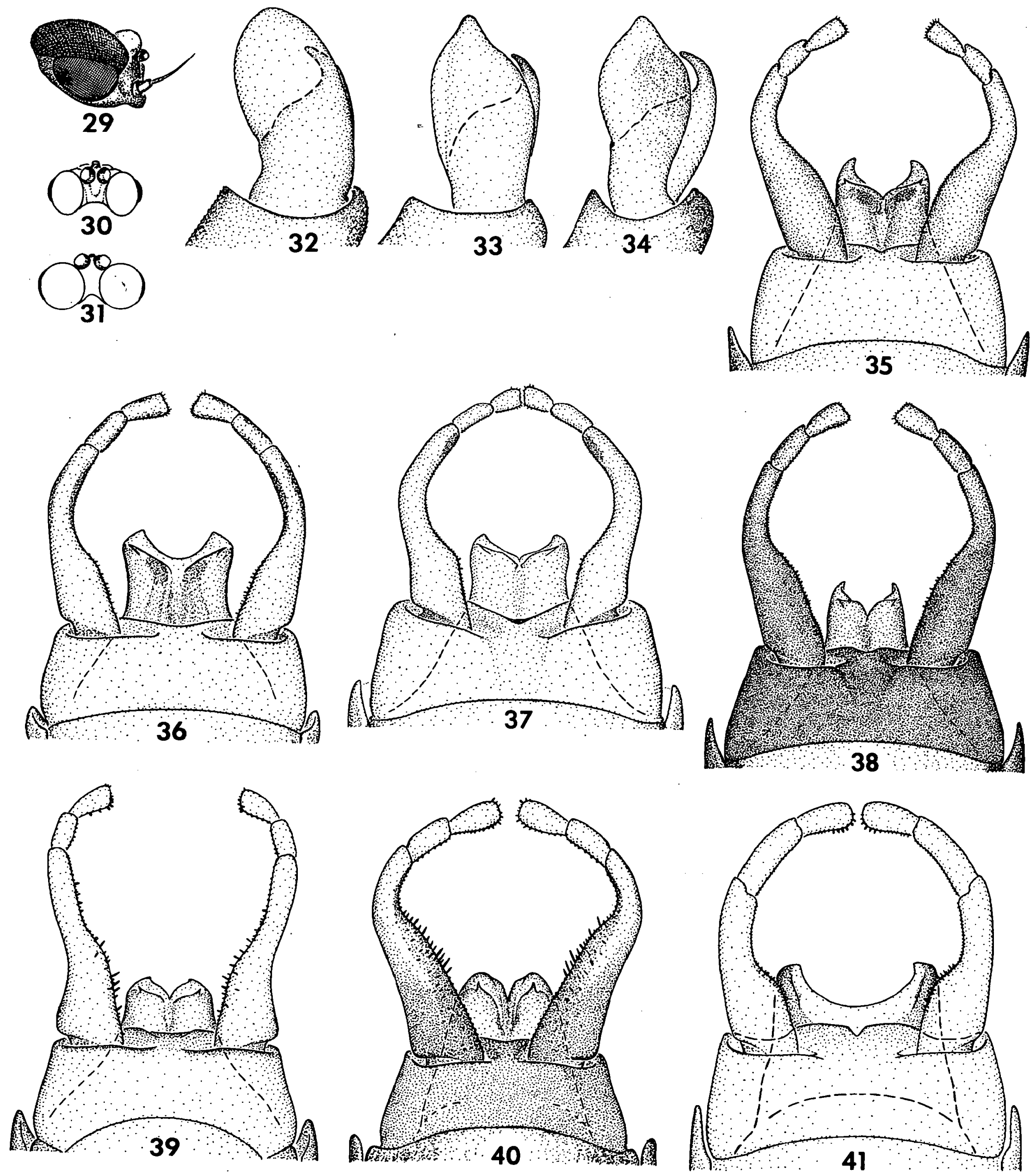

Figs. 29-41. male imago. Fig.29-31, lateral (29) and dorsal views (30-31) of eyes : 29-30, Amoa fronini ; 31, A. orthogonia. Fig. 32-34, fore claw : 32, Paraluma triangularis ; 33, Oumas orbis ; 34, Amoa fronini. Fig 35-41, genitalia (ventral) : 35 , Paraluma cancellata ; 36, $P$. triangularis ; 37, P. gilva ; 38, P. pulla ; 39, P. maculata ; 40, P. minuta ; 41, Oumas orbis.

Figs 29-41. imagos mâles. 

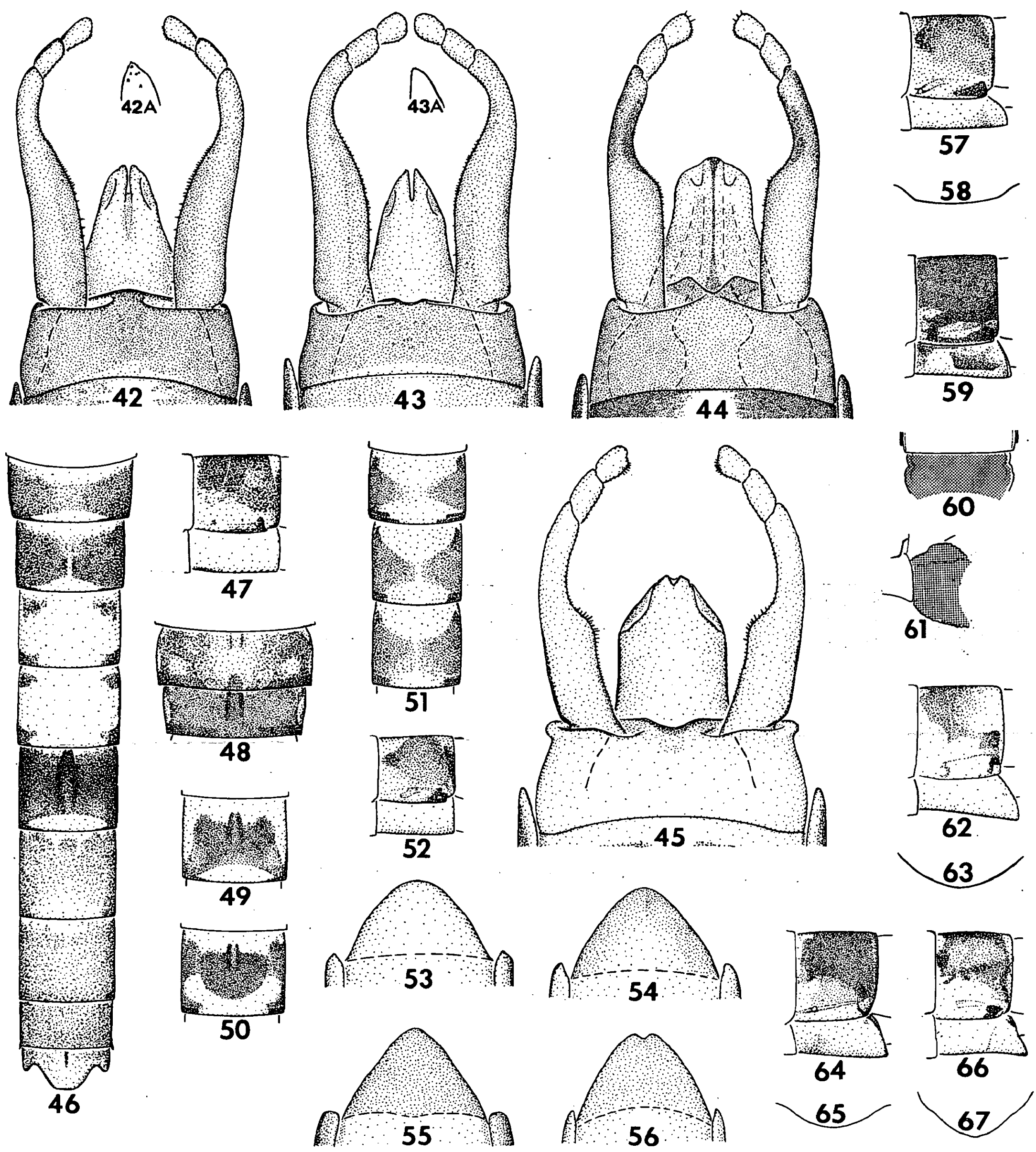

Figs. 42-45. genitalia (ventral) of $\sigma^{\prime}$ imago with detail of penis lobe (A). 42, Amoa fronini ; 43, A. subsolana subsolana; 44, A. hebes; 45, A. orthogonia. Fig. 46-52, abdominal pattern of imagos : 46-50, Paraluma cancellata ; 51-52, $P$. triangularis. Fig. 53-67, 9 imago : 53, 57-58, Paraluma triangularis ; 59-61, P. minuta ; 54, 62-63, Oumas orbis ; 55, 64-65, Amoa fronini ; 56, 66-67, A. orthogonia. Male terga 2-10 (46), 5$7(51)$, lateral $\sigma^{\top}$ segment $6(47,51)$, $\$$ terga 5-6 (48), ơ tergum 6 variation $(49-50)$. Female sternum $9(53-56)$, lateral view $(57,59,62,64,66)$ and posterior stemal margin of segment $7(58,60,63,65,67)$; ventral and lateral position of egg mass $(60-61)$.

Figs 42-45. imagos mâles et femelles. 

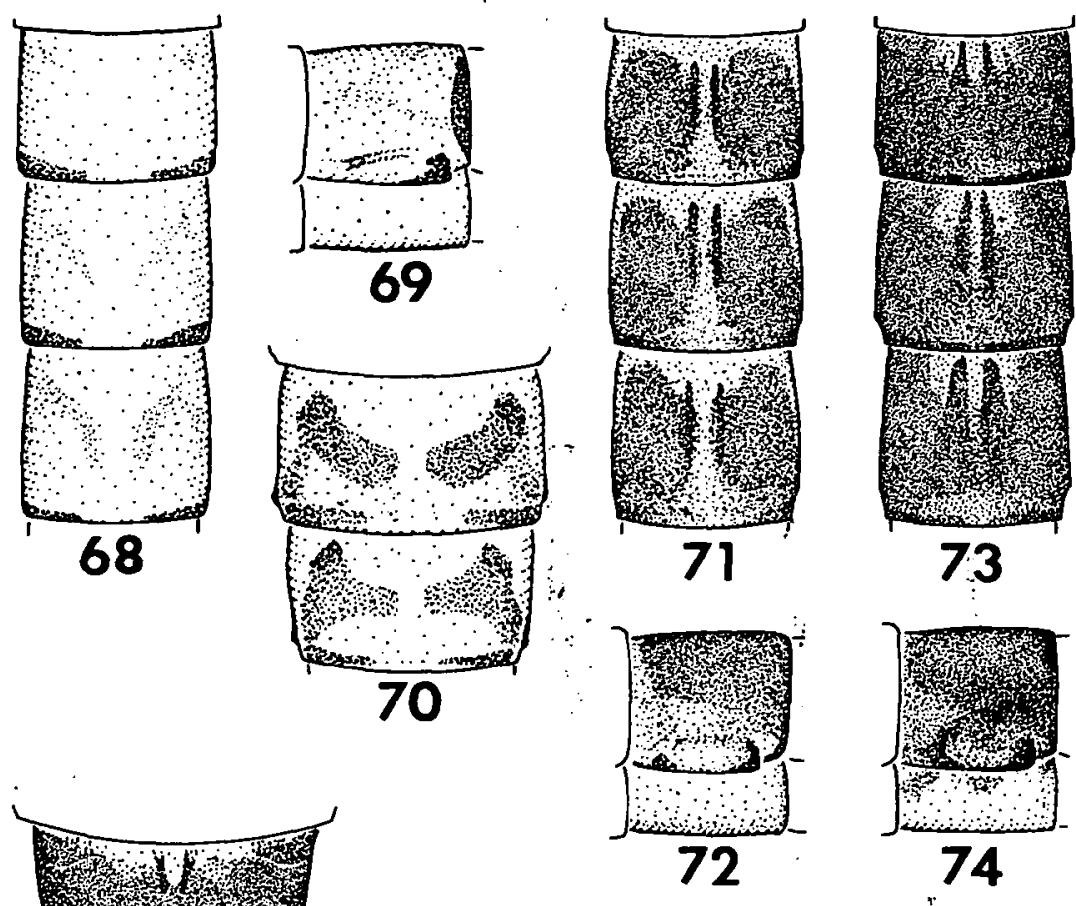

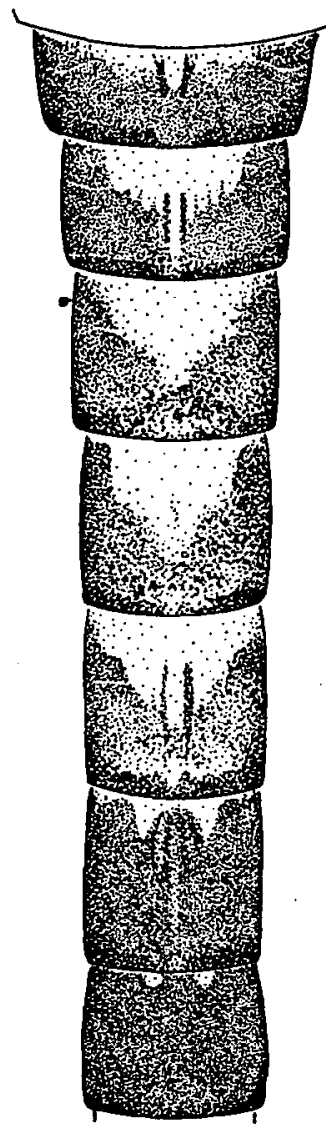

81

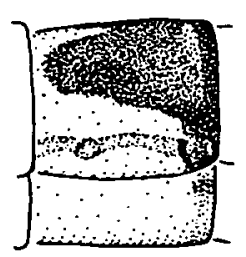

82

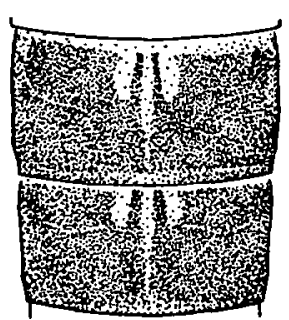

83

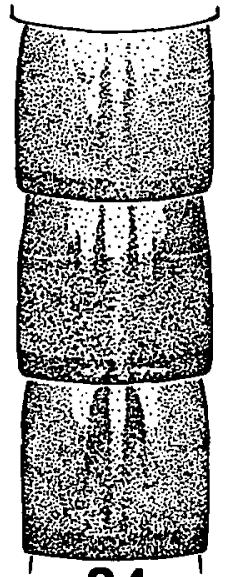

84

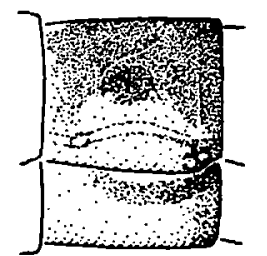

85
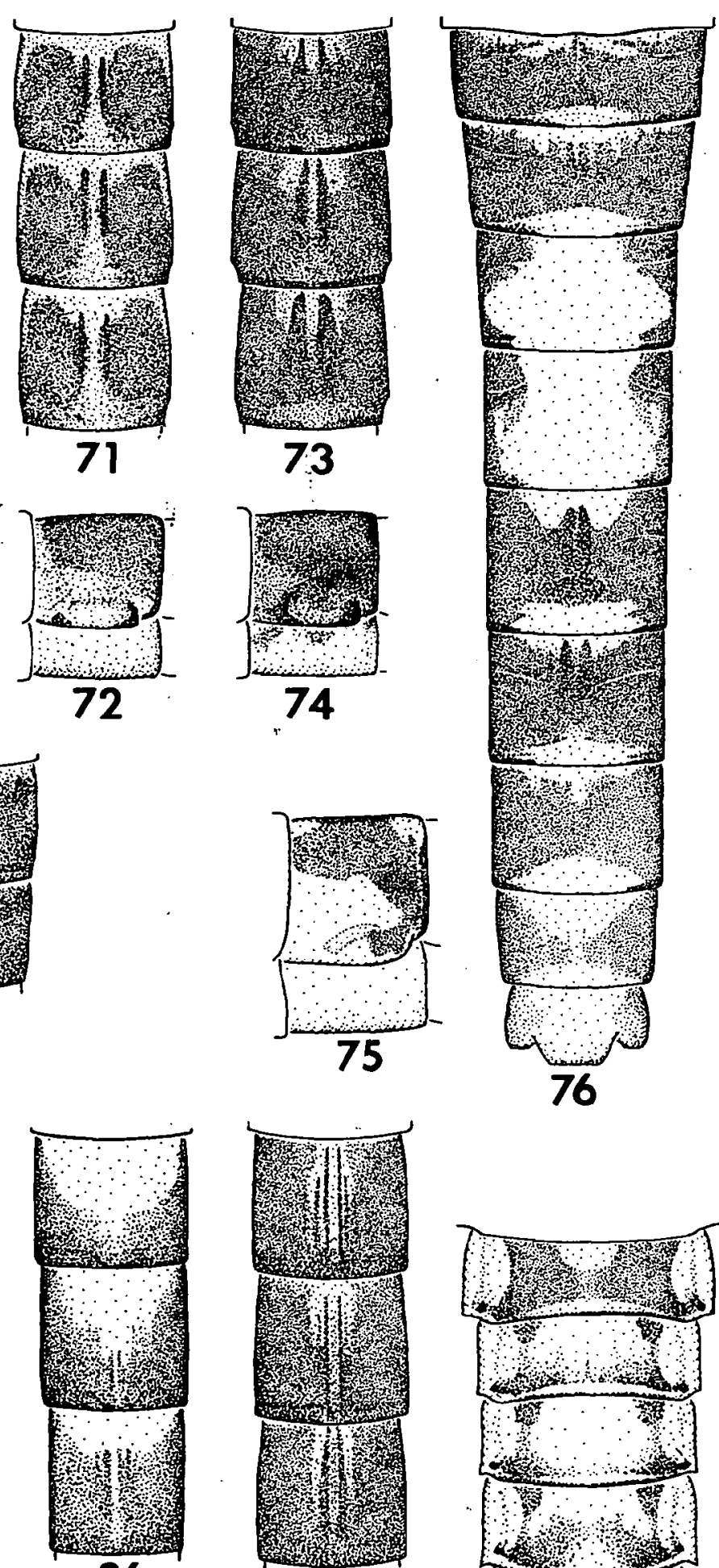

88

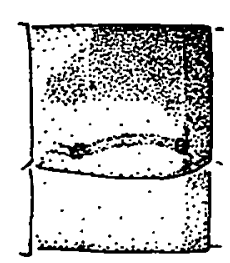

87
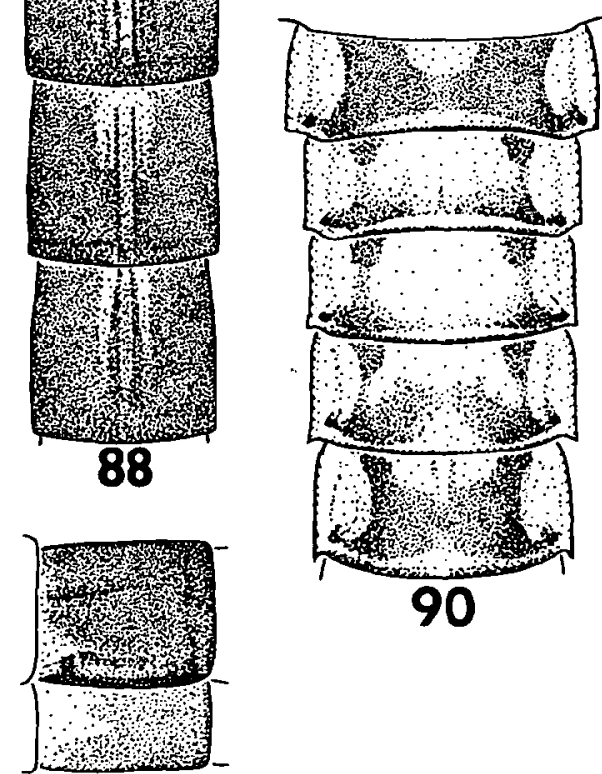

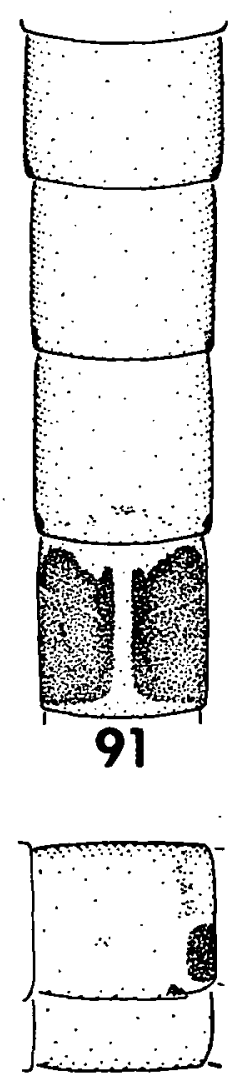

92
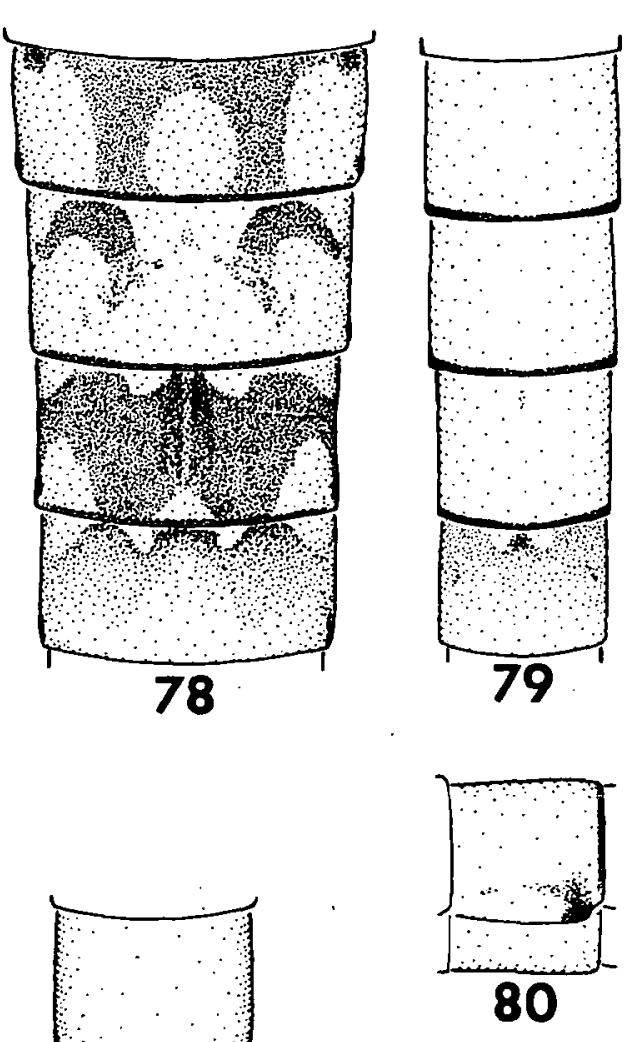

Figs. 68-89, 91-93. color patterns of imagos. 68-70, Paraluma gilva ;71-72, P. pulla ;73-74, P. minuta ;75-76, P. maculata; 77-80, Oumas orbis ; 81-83, Amoa fronini ; 84-85, A. subsolana subsolana ; 86-87, A. subsolana caerulea ;88-89, A. hebes ; 91-93, A. orthogonia. Fig. 90, abdominal terga 3-7 of pre-emergent $\sigma^{7}$. nymph of $A$. cressonensis. Abdominal terga of $\sigma^{\top}: 2-10(76), 2-8(81) ; 4-7(79,91), 5-7(68,71,73), 4-6$ $(84,86,88)$; of $\$ 4-7(78,93), 5-6(70,83)$. Lateral view of abdominal segment $6(69,72,74,75,80,82,85,87,89,92)$. Fore femur of $\$(77)$.

Figs 68-89, 91-93. colorations imaginales. 

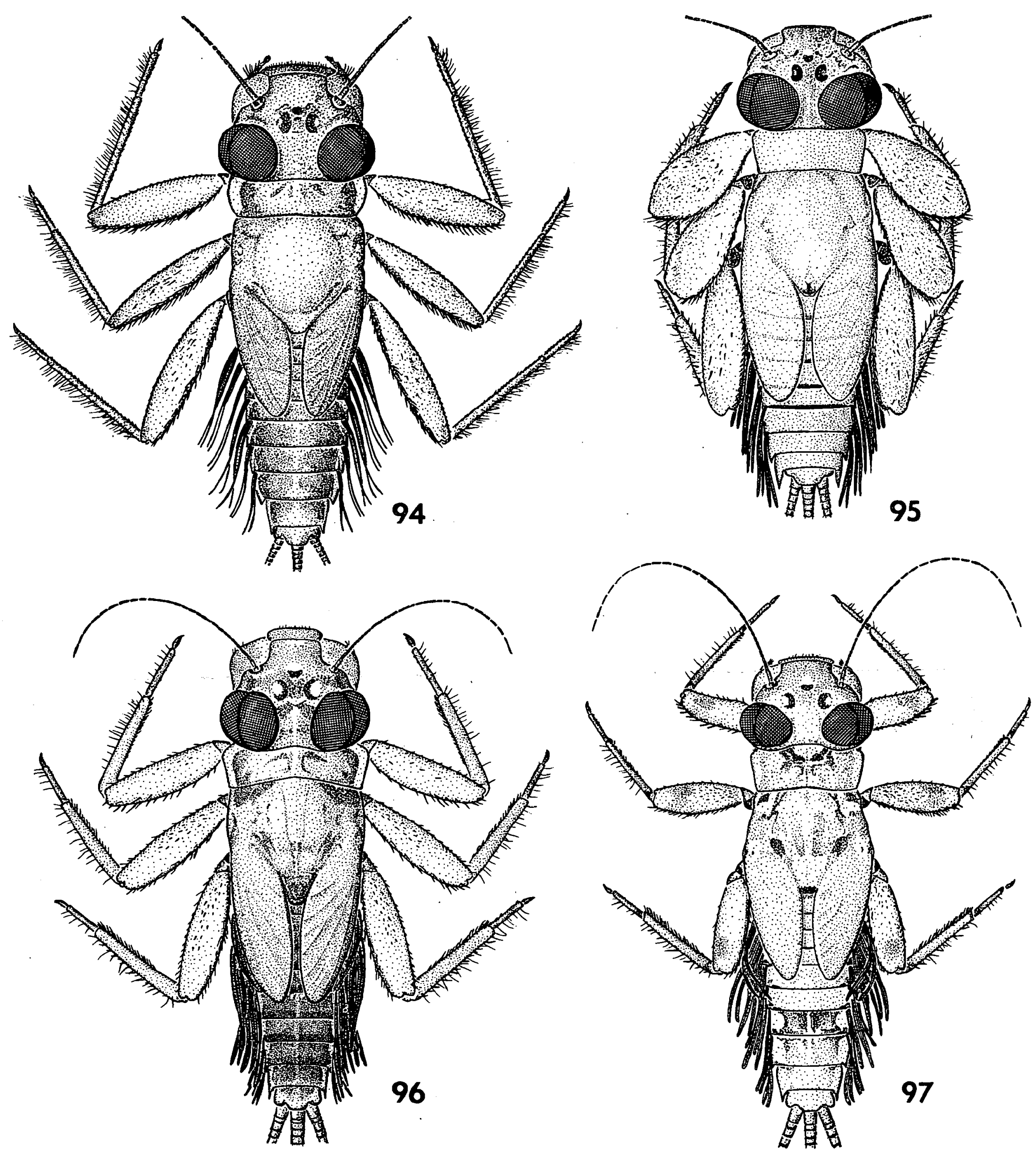

Figs. 94-97. mature male nymph. 94, Paraluma triangularis ; 95, Oumas orbis ; 96, Amoa subsolana caerulea ; 97, A. orthogonia.

Figs 94-97. larves mâles matures. 

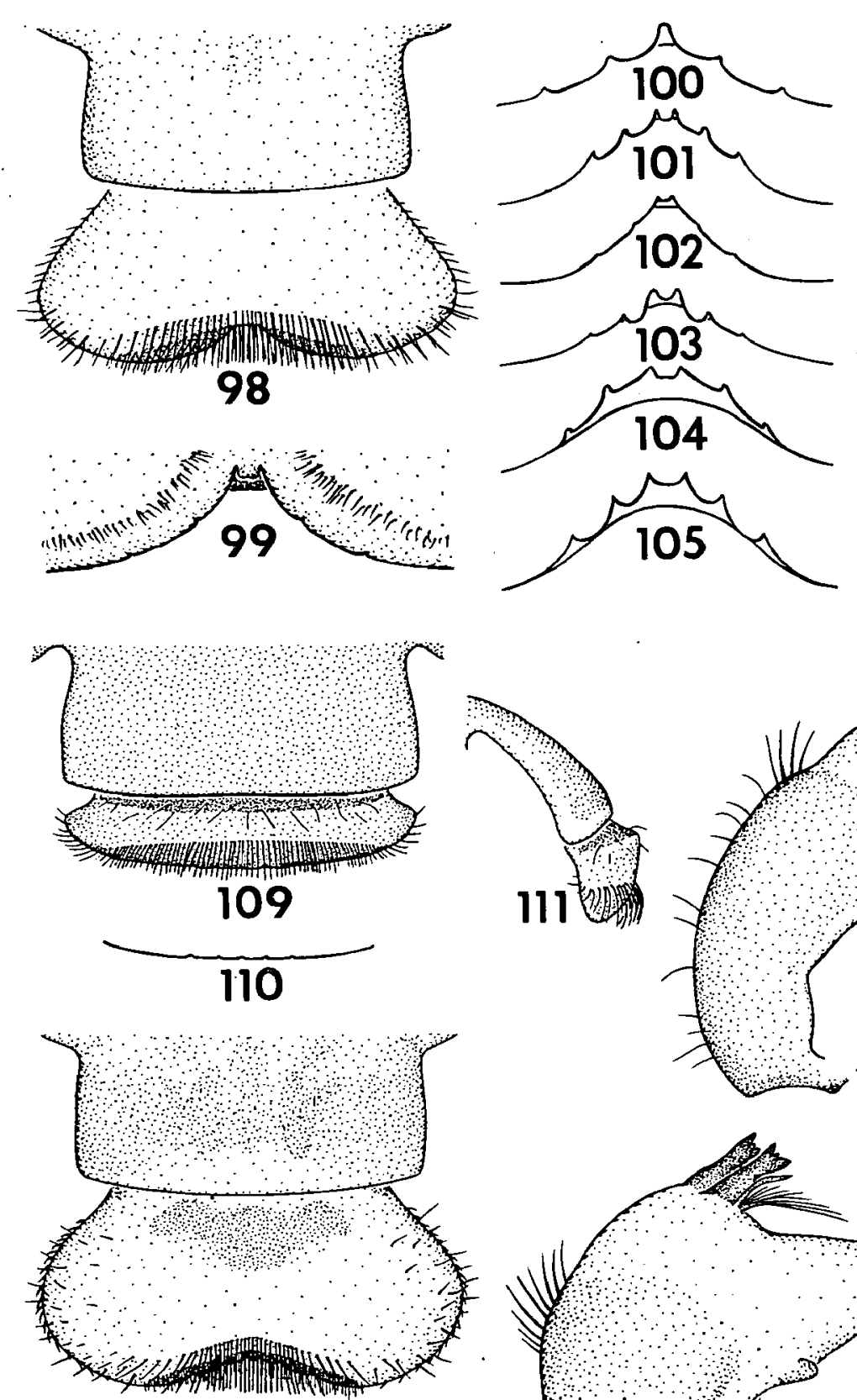

115
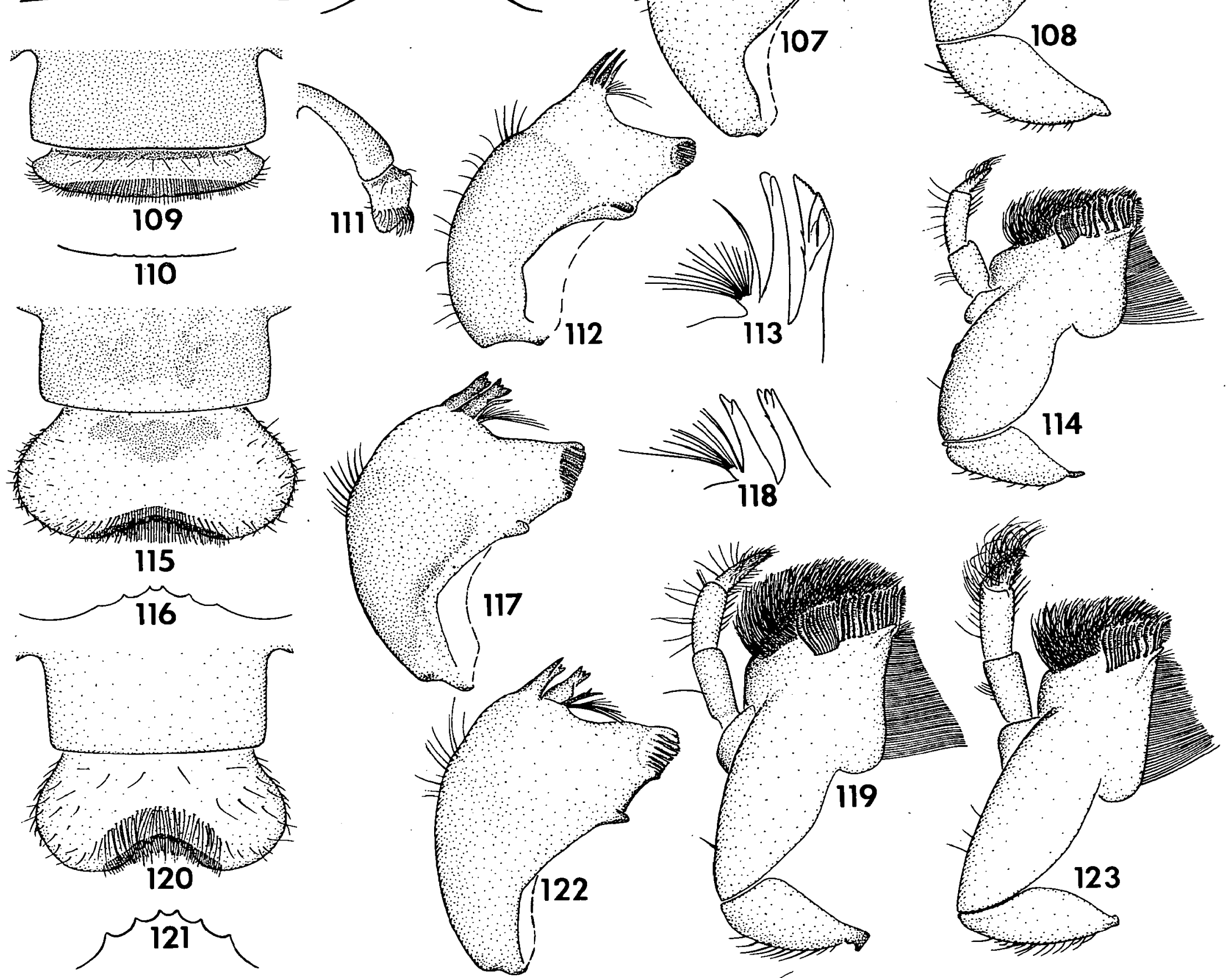

Figs. 98-123. mouthparts of nymph. 98-99, 106-108, Paraluma triangularis; 100-102, P. cancellata ; 103, P. gilva; 104, P. pulla; 105, P. minuta ; 109-114, Oumas orbis ; 115-119, Amoa fronini ; 120-123, A. orthogonia. Labrum and clypeus (dorsal 98,109,115,120; lateral 111) with detail of anteromedian margin $(99-105,110,116,121)$. Left mandible $(107,112,117,122)$ and detail of incisors of right mandible $(106,113,118)$. Right maxilla, ventral $(108,114,119,123)$.

Figs. 98-123. pièces buccales de larves. 

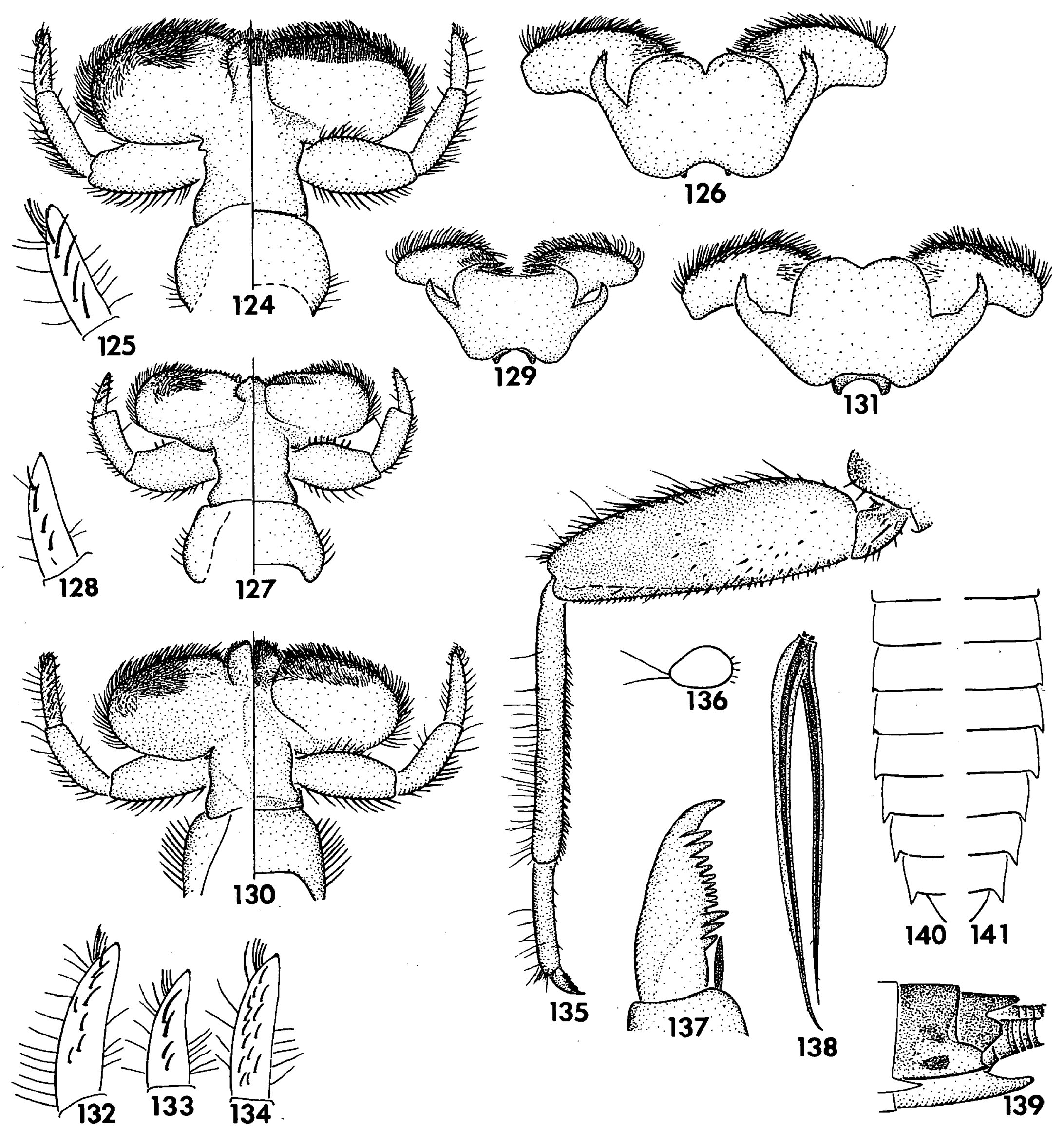

Figs. 124-141. structures of nymph. 124-126, 136-139, Paraluma triangularis ; 135, P. pulla ; 140-141, P. cancellata, 127-129, Oumas orbis ; 130-131, Amoa fronini ; 132, A. subsolana subsolana ; 133, A. orthogonia ; 134, A. cressonensis. Labium $(124,127,130)$ and dorsal detail of third palpal segment $(125,128,132-134)$. Hypopharynx $(126,129,131)$. Foreleg (135), cross section of tibia (136), foreclaw (137). Gill 4 (138). Abdominal segment 9-10, lateral (139). Margin of abdominal sterna 3-10 (140-141).

Figs. 124-141. structures larvaires. 


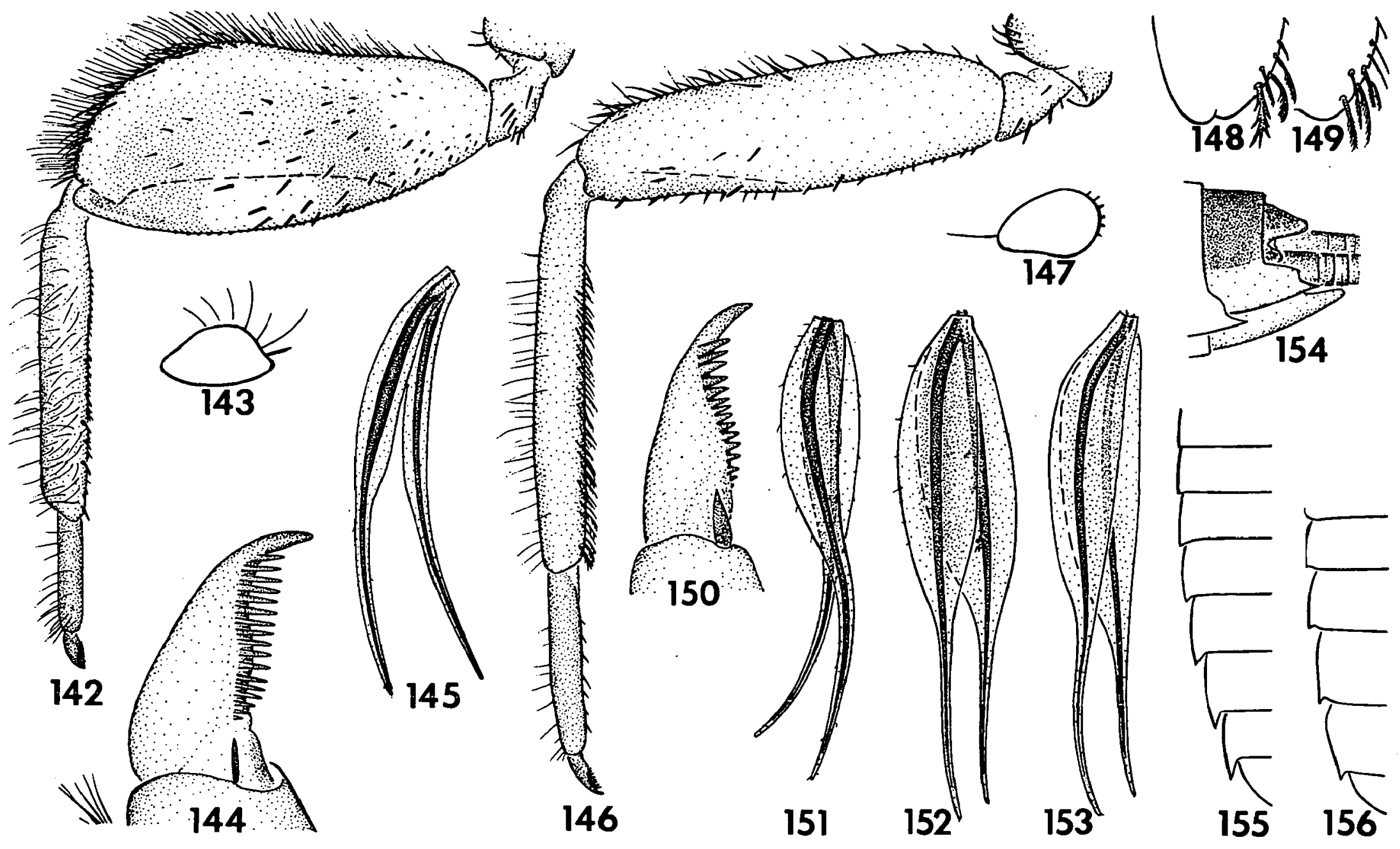

Figs. 142-156. structures of nymph. 142-145, Oumas orbis ; 146-151,154-155, Amoa fronini ; 152, A. cressonensis ; 153,156, A. orthogonia. Foreleg $(142,146)$, cross section of tibia $(143,147)$, apex of tibia (148-149), foreclaw $(144,150)$. Gill 4 (145,151-153). Abdominal segment 9-10, lateral (154). Margin of abdominal sterna 3-10 (155), 5-10 (156).

Figs. 142-156. structures larvaires.

Discussion. Paraluma can be distinguished from all genera of the Atalophlebiinae by the following combination of characters. In the imagos : (1) the CuA area of the fore wings possesses 2 long intercalaries (Fig. 1, 7 ) and vein MA is forked symmetrically ; (2) in the hind wings, costal projection is rounded and length of vein $\mathrm{Sc}$ is $3 / 5$ to $2 / 3$ maximum length of hind wings (Fig. 2-6, 8-9) ; (3) claws of a pair are dissimilar ; one is apically hooked while other is obtuse, pad-like (Fig. $32)$; (4) penes of $\sigma^{7}$ genitalia are fused except at apex ; a broad dorsal spine occurs near apex of each penis lobe (Fig. 35-40) ; and (5) the ninth sternum of $Q$ is entire apically (Fig. 53). In the nymph : (1) anterior margin of lingua of hypopharynx is cleft ; apex of submedian lobes each possess a rake-like process (Fig. 126) ; (2) segment 3 of labial palpi is $2 / 3$ to $3 / 4$ maximum length of segment 2 (Fig. 124); (3) outer margin of mandibles is smoothly curved and a thick tuft of hair occurs near the middle of the outer margin (Fig. 107) ; (4) basal 3 denticles of claws are broad and progressively larger apically ; remaining denticles are thin and progressively larger apically (Fig. 137) ; and (5) labrum is broad apically with a deeply cleft anteromedian margin and 4-5 ventral denticles (Fig. 98-105).

Paraluma appears to be most closely related to $\mathrm{Ou}$ mas and can be distinguished from Oumas by the following combination of characters. In the imagos : (1) penes of $\sigma^{7}$ genitalia are fused except at apex ; a broad ventral spine or flap is present near the apex of each 
penis lobe (Fig. 35-40) ; and (2) eyes of $\sigma^{\circ}$ are separated by a distance greater than width of median ocellus. In the nymph : (1) basal 3 denticles of claws are broad and progressively larger apically ; remaining denticles are thin and progressively larger apically (Fig. 137) ; (2) anteromedian margin of labrum is acutely cleft (Fig. 98-105) ; and (3) femora of fore legs are not broad distally (Fig. 135). The first two nymphal characters will also separate Paraluma from Amoa ; further, the narrow, smoothly tapered gills distinguish nymphs of Paraluma from those of Amoa.

Among some specimens of $q$ imagos ( $P$. triangularis, $P$. minuta), eggs are retained in a partially extruded condition. Based on these specimens, it appears that eggs of Paraluma are extruded in mass (Fig. 60-61).

\section{Keys to the Species of Paraluma, new genus}

\section{MALE AND FEMALE IMAGOS}

1. Abdominal terga 4-5 with pale median area (Fig. 46, 48, 76), other terga darker

-- Color pattern on abdominal terga 4-5 similar to that on other terga (Fig. 51, 68, 70-71, 73) 3

2. Abdominal tergum 6 with blackish-brown, saddle-shaped markings much darker than markings on terga 3-4, 7-8 (terga 7-8 pale brown) (Fig. 46, 48-50) ; total length of body (head to tergum 10) $\geq 5.0 \mathrm{~mm}$ P. cancellata

-- Dark brown color on abdominal tergum 6 of same intensity as that on terga $2-3,7-8$ (Fig. 76) ; total length of body (head to tergum 10) $\leq 4.0 \mathrm{~mm}$ P. maculata

3. Dorsum of abdominal terga entirely brown to blackishbrown, sometimes with a pale narrow, median line (Fig. 71, 73)

... 4

-- Dorsum of abdominal terga not as above, either with submedian triangular marks (Fig. 51), or very pale marks (Fig. 68, 70)

5

4. Total length of body (head to tergum 10 ) $\geq 5.0 \mathrm{~mm}$; dark color of terga 1-8 paler anteriorly and anterolaterally (Fig. 71-72) ; penis lobes of $O^{\prime}$ acute laterally (Fig. 38) ; caudal filaments brown, sometimes a little darker brown at basal annulations P. pulla

-- Total length of body (head to tergum 10) $\leq 4.0 \mathrm{~mm}$; dark color of terga 1-8 paler at anterior and anterosubmedian margin only (Fig. 73) ; penis lobes of $\sigma^{\circ}$ apically rounded (Fig. 40) ; caudal filaments pale ........................ P. minuta

5. Dark brown, triangular lateral marks on terga 2-6 as in Fig. 51-52 ; caudal filaments with dark annulations at articulations, at least in basal segments P. triangularis

-- Lateral areas of terga 2-6 with paired, brownish, oblique marks (Fig. 70, \%) to oblique marks faded or absent (Fig. $\left.68-69,0^{7}\right)$; caudal filaments pale to light yellow-brown P. gilva

\section{MATURE NYMPHS}

1. Color pattern of terga 1-9 uniformly dark brown ; median denticle on anteromedian emargination of labrum about same size as lateral denticles (Fig. 104-105) ................. 2

--Abdominal terga 1-9 patterned with lighter and darker areas ; median denticle on anteromedian emargination of labrum smaller than lateral denticles or median denticle absent (Fig. 99-102)

2. Abdominal sterna 2-9 pale ; posterior margin of scutellum light brown to brown (same color as mesonotum) ; total length of body of mature nymph (head to tergum 10) $\geq 4.5$ $\mathrm{mm}$ P. pulla

-- Abdominal sterna 2-9 with dark brown sublateral marks ; posterior margin of scutellum blackish-brown (darker than brown mesonotum) ; total length of body of mature nymph (head to tergum 10) $\leq 4.0 \mathrm{~mm}$............... P. minuta

3. Median area of terga 4-5 paler than tergum 6 ; tergum 6 with blackish-brown marks similar to those of imago (Fig. 46, 48-50) $P$. cancellata

-- Color pattern on terga 4-5 same as that on tergum 6 ....... 4

4. Terga 2-9 with dark brown sublateral triangular marks (Fig. 94) similar to those of imagos (Fig. 51-52) P. triangularis

-- Terga 2-9 with small median marks similar to those of imagos (Fig. 68, 70) P. gilva

\subsection{Paraluma cancellata, new species}

(Figs. 1-3, 35, 46-50, 100-102, 140-141)

\section{Male imago (in alcohol)}

Length : body 5.0-5.2 $\mathrm{mm}$; fore wings $5.5-5.8 \mathrm{~mm}$. Upper portion of eyes reddish-brown, lower portion black. Head brown, vertex and anterior margin washed heavily with dark blackish-brown. Antennae brown, flagellum paler. Thorax brown, carinae darker, sutures paler, margins and median carina of pronotum blackish-brown, margins and median of mesoscutellum pale, carinae of pleura dark blackish-brown especially near base of legs and wings. Coxae brown washed with darker brown, remainder of legs pale, except prothoracic femora brown, apex of femora and tibiae blackishbrown. Wings (Fig. 1-3) : longitudinal veins of fore and hind wings brown, veins darkest at base of costal brace, faded in posterior half of fore and hind wings ; membrane of fore and hind wings hyaline, light brown, except apical 1/3 of cells $C$ and Sc of fore wings translucent, brownish-white. Abdomen : light brown, segments 1-7 translucent, segments 8-10 opaque ; terga 1 and 9-10 uniformly washed with darker brown, terga 2-7 washed with darker brown as in Fig. 46, median area of terga 4 and 5 pale, median area of tergum 6 dark brown to black, terga 7-8 light brown (Fig. 46-47, 49-50) ; spiracles and surrounding area dark blackish- 
brown, tracheae hyaline edged with blackish-brown ; sternum 1 with darker brown, oblique bars. Genitalia (Fig. 35) : brown. Caudal filaments pale, articulations with narrow, darker brown annulations, annulations faded near apex of caudal filaments.

\section{Female imago (in alcohol)}

Length : body 4.9-6.0 mm ; fore wings 5.5-6.8 mm. Eyes black. Head brown, area between ocelli and area along anterior and posterior margins washed with darker blackish-brown. Antennae brown, flagellum paler. Thorax : color and marks as in $\sigma^{*}$ imago. Legs : color and marks as in $\sigma^{\prime}$ imago, except apex of tibiae paler. Wings : color and marks as in $0^{7}$ imago, except membrane of fore and hind wings darker. Abdomen : color and marks as in $\sigma^{7}$ imago, except median area of terga 4-5 darker, less open (Fig. 48) ; tracheae darker. Caudal filaments : color and marks as in $0^{\prime}$ imago.

\section{Mature nymph (in alcohol)}

Head brown, darker blackish-brown marks as in $0^{7}$ and $\%$ imagos. Thorax : brown, venter paler, marks as in $\sigma^{\top}$ and $\$$ imagos. Legs : pale, darker blackish-brown marks at apex of femora and tibiae faded on prothoracic legs and absent on mesothoracic and metathoracic legs. Abdomen : color and marks in $\sigma^{\circ}$ and $\%$ imagos. Gills : membrane translucent gray, tracheae black. Caudal filaments pale.

\section{Specimens}

Holotype $\sigma^{*}$ imago, No. N13 ; allotype $Q$ imago, No. N13 ; paratypes : 5 nymphs, 114 ơ, 29 ㅇ, No. N13 ; 1 o", No. N15; 2 O’ subimagos, No. N16; 2 ơ, 2 우, No. N26; 8 nymphs, 10 ơ, 26 \&, No. N28; 1 ơ, 1 \%, No. N34; 7 o', 1 ơ subimago, 24 \%, No. N37 ; 3 ơ, 1 ., No. N40; 14 ơ, 1 ơ subimago, 20 \&, No. N41; 42 O', 14 ơ subimagos, 209 \&, 3 \% subimagos, No. N42 ; 6 \%, No N54; 5 nymphs, No. FNK4 ; 12 nymphs, No. FNK5 ; 1 nymph, No. FNK10,11,13; 1 nymph, No. FNK30 ; 8 nymphs, No. FNK35; 46 nymphs, No. FNK62 ; 19 nymphs, No. FNK66 ; 53 nymphs, No. FNK67; 15 nymphs, No. FNK68; 9 nymphs, No. FNK72 ; 1 nymph, No. FNK79 ; 1 nymph, No. FNK80 ; 3 nymphs, No. FNK87 ; 5 nymphs, 1 ㅇ, No. FNK8889 ; 49 nymphs, No. FNK94 ; 10 nymphs, No. FNK95 ; 15 nymphs, No. FNK104 ; 21 nymphs, No. FNK105 ; 2 nymphs, No. JI2. All types are in alcohol. Association of the nymphs and adults is by the abdominal color pattern on the terga of specimens from the same locality. Type depositions : holotype, allotype and paratypes at FAMU, except : $300^{\prime}, 50$ \%, $20^{\prime \prime}$ subimaginal and 30 nymphal paratypes each at each at BPBM, ORSTOM, CTFT, and NMNH. One very pale ơ from $\mathrm{N} 27$ is not included in the type series.
Etymology cancellus, L., meaning bar.

Discussion. Paraluma cancellata can be distinguished from the remaining species of Paraluma by the characters given in the key. The abdominal color pattern on the $q$ imaginal terga is variable at most localities collected, and there is a great deal of variation in terga of the $\sigma^{\circ}$ imagos. In those from the type locality, tergum 3 is almost as dark as tergum 6 but in specimens from the East Coast, the dorsal and lateral marks on terga 2-3 are faded. The shape of the dark mark on tergum 6 varies between localities (Fig. 46, 49-50) ; generally, $\sigma^{\prime}$ and $\%$ imagos from the Southern Region are paler. Posterolateral spines occur on terga 3 or 4-9 of nymphs and are often larger on nymphs from the East Coast (Fig. 141), although this character varies within localities. Some variation in detail of the margin of the labrum is given in Fig. 100-102.

Biology : Paraluma cancellata is a common species which occurs throughout New Caledonia. Nymphs were found in streams with water temperatures of 15.2$25^{\circ} \mathrm{C}$ and at $31-458 \mathrm{~m}$. The species was most abundant in streams with water temperatures of $18-20.5^{\circ} \mathrm{C}$.

Nothing is known about the habits of the nymphs. Imagos swarm in large companies (100 or more) over the river at dusk. On one occasion at locality No. N13, a large swarm was swept by wind into a light trap and many imagos settled on the white sheet. Nymphs probably emerge about one hour after dark, as many subimagos were then collected at light trap.

\subsection{Paraluma triangularis, new species}

(Figs. 4, 23-24, 32, 36, 51-53, 57-58, 94, 98-99, 106108, 124-126, 136-139)

\section{Male imago (in alcohol)}

Length : body $6.2-6.8 \mathrm{~mm}$; fore wings $6.0-6.5 \mathrm{~mm}$. Upper portion of eyes reddish-brown, lower portion black (Fig. 23). Head light brown, washed heavily with dark blackish-brown except on vertex. Antennae light brown, flagellum paler. Thorax light brown, notum paler, carinae darker, sutures paler, margins and median carina of pronotum blackish-brown, carinae of pleura dark blackish-brown especially near base of legs and wings. Coxae light brown with a blackishbrown macula ; prothoracic femora brownish, femorotibial articulation and apex of tibiae darker ; remainder of legs pale. Wings (Fig. 4) : longitudinal veins of fore and hind wings light brown, veins faded in $\mathrm{CuA}$ area of fore wings and posterior half of hind wings, cross veins lighter brown, veins faded in posterior half of fore and hind wings; membrane hyaline, light brown, except apical $1 / 3$ of cells $C$ and Sc of fore wings translucent, brownish-white. Abdomen : light yellow- 
brown, segments 1-7 translucent, segments 8-10 opaque ; terga 1 and 9-10 uniformly washed with darker brown, terga 2-8 with dark brown triangular marks, median points of triangles adjacent on posterior terga (usually terga 6-8) as in Fig. 51 ; antero- and posteromedian areas of terga 2-8 pale (Fig. 51) ; spiracles and surrounding area dark blackish-brown, tracheae washed heavily with dark blackish-brown; sternum 1 washed lightly with brown and darker brown oblique bars, sternum 2 with paired, sublateral, small, faint, darker brown maculae. Genitalia (Fig. 36) : light brown, inner margin near apex of forceps segment 1 darker. Caudal filaments pale, articulations with narrow dark brown annulations, annulations faded apically.

\section{Female imago (in alcohol)}

Length : body $5.0-5.5 \mathrm{~mm}$; fore wings $6.2-7.5 \mathrm{~mm}$. Eyes black. Head light brown, area around ocelli washed with darker blackish-brown. Antennae light brown, flagellum pale. Thorax : color and marks as in $\sigma^{\prime}$ imago. Legs : color and marks as in o' imago, except darker brown marks at apex of femora and tibiae faded. Wings : color and marks as in $\sigma^{7}$ imago, except veins and membrane of fore and hind wings darker. Abdomen : color and marks as in o' imago (Fig. 51-52, 57), except median pale area on terga $2-9$ larger, sternum 1 paler. Caudal filaments : color and marks as in ơ imago.

\section{Mature nymph (in alcohol) (Fig. 94)}

Head light brown, darker blackish-brown as in $\sigma^{\circ}$ and $O$ imagos. Thorax : light brown, venter paler, darker marks as in $\sigma^{\prime}$ and $q$ imagos. Legs : pale, darker blackish-brown marks at apex of femora and tibiae faded. Abdomen : color and marks as in $\sigma^{\circ}$ and $\$$ imagos, except tergal color pattern faded in $\sigma^{\prime \prime}$, marks on sterna 1 and 2 of $\sigma^{\circ}$ and $\$$ faded. Gills (Fig. 138) : membrane translucent gray, tracheae black. Caudal filaments pale.

Specimens. Holotype ơ imago, No. N35 ; allotype ? imago, No. N54 ; paratypes : 52 nymphs, 30 ơ, 1 \% subimago, $17 \%, 2$ subimagos, No. N13;2 nymphs, No. N25; 54 nymphs, 32 ơ $^{\prime}, 60^{7}$ subimagos, $6 \%, 1$ \% subimago, No. N27; 74 nymphs, $14 \%, 2$ subimagos, No. N28; 3 nymphs, 14 ơ, 2 \%, 1 \% subimago, No. N35 ; 13 nymphs, No. N51; 4 nymphs, No. N53 ; 3 nymphs, 34 ơ, 5 ơ subimagos, 6 \%, 2 \% subimagos, No. N54; 42 nymphs, 1 O’ subimago, 1 \%, No. N55; 2 nymphs, No. FNK 23-24; 20 nymphs, No. FNK59. All types are in alcohol. Association of the nymph and adults is by rearing. Type depositions : holotype, allotype and paratypes at FAMU, except : $200^{\circ}, 7 \%, 20^{\circ}$ subimaginal, $1 \%$ subimaginal and 40 nymphal paratypes each at BPBM, ORSTOM, CTFT, and NMNH. Additional material : 25 nymphs, 3 ơ, 6 \%, 1 \% subi- mago, No. N37; 1 subimago, No. N41; 10 subimago and 1 \% subimago, No. N42; 1 nymph, No. N50 ; 2 nymphs, No. N52; 10 nymphs, No. FNK18-20 ; 1 nymph, No. FNK $55 ; 5$ nymphs, No. FNK63; 10 , No. FNK82; 1 nymph, No. FNK95. Type specimens are restricted to good material from southern localities because of the possible confusion of $P$. triangularis with $P$. gilva. Where both species overlap (No. N37), not all $\%$ subimagos can be placed to species.

The triangular marks on terga 2-8 of the $\sigma^{\prime}$ imagos are paler and indistinct on occasional specimens from various localities, especially locality No. N54.

Etymology. triangulus, L., having three angles.

Discussion. Paraluma triangularis can be distinguished from the remaining species of Paraluma by characters given in the key.

Biology. Paraluma triangularis occurs throughout New Caledonia. Nymphs were found in streams with water temperatures of $16.6-23^{\circ} \mathrm{C}$ and from $31-458 \mathrm{~m}$. The species was most abundant in streams with water temperatures of $18-23^{\circ} \mathrm{C}$.

Nymphs are found on and between small rocks in faster areas of a stream. Imagos swarm over the river after dark and many were collected at light trap. Nymphs probably emerge after dark, as many subimagos were collected late at light.

\subsection{Paraluma gilva, new species}

(Figs. 37, 68-70, 103)

\section{Male imago (in alcohol)}

Length : body $4.5-5.3 \mathrm{~mm}$; fore wings $5.5-6.1 \mathrm{~mm}$. Upper portion of eyes reddish-brown, lower portion black. Head light brown, anterior margin washed with blackish-brown. Antennae light brown, flagellum paler. Thorax light brown, carinae darker, sutures paler, margin of pronotum blackish-brown, areas around base of wings and legs blackish-brown. Coxae light brown with blackish-brown macula ; prothoracic femora light brown, brown at apex of femora and base and apex of tibiae; remainder of legs pale. Wings : longitudinal and cross veins of fore and hind wings and posterior half of hind wings hyaline, except $C$ and $\mathrm{Sc}$ of fore wings and wing bases light brown and apical $1 / 3$ of cells $C$ and $S c$ of fore wings translucent, brownish-white. Abdomen : segments 1-6 opaque, pale yellow-brown ; terga 1-9 with a narrow, transverse, blackish-brown band on posterior margin, band faded on median of each tergum, and lighter on tergum 9, lateral margins of tergum 1 washed heavily with blackish-brown, terga 6-10 washed lightly with paired, lateral, oblique, brownish marks (Fig. 68-69) ; area around 
spiracles blackish-brown, tracheae washed lightly with blackish-brown ; sternum 1 with faint, darker brown oblique bars. Genitalia (Fig. 37) : pale yellow-brown, inner margin of forceps segment 1 darker near apex. Caudal filaments pale yellow-brown.

Female imago (in alcohol)

Length : body 5.5-6.0 $\mathrm{mm}$; fore wings $6.8-7.5 \mathrm{~mm}$. Eyes black. Head light brown, areas around ocelli washed with darker brown. Antennae light brown. Thorax : color and marks as in $\sigma^{\prime}$ imago, except prothoracic femora paler, apex of prothoracic tibiae pale. Wings : color and marks as in O’ imago, except color of membrane of fore and hind wings darker. Abdomen : color and marks as in ơ imago, except marks light brown, terga 2-9 with paired, lateral, darker brown, oblique marks as in Fig. 70 ; paired, lateral, oblique marks on sternum 1 darker. Caudal filaments pale.

Mature nymph (in alcohol)

Head brown, venter lighter, darker brown marks as in $\sigma^{\prime}$ and $\%$ imagos. Thorax : brown, venter paler, darker blackish-brown marks as in $\sigma^{\circ}$ and $\$$ imagos. Legs : pale, all marks as in $\sigma^{\prime}$ and $\$$ imagos absent. Abdomen : brown, venter paler, marks as in $\sigma^{\circ}$ and $\$$ imagos, except marks on terga obscured. Gills : membrane translucent gray, tracheae black. Caudal filaments pale.

Specimens. Holotype ơ imago, No. N37 ; allotype $\$$ imago, No. N37 ; paratypes : $40^{\circ}, 40^{\circ}$ subimagos, 3 o subimagos, 95 nymphs, No. N37. All types are in alcohol. Association of the nymph and adults is by rearing. Type depositions : holotype, allotype and paratypes at FAMU, except : $10^{\circ}, 10^{\circ}$ subimaginal, $1 \%$ subimaginal, and 18 nymphal paratypes each at NMNH and ORSTOM, 18 nymphal paratypes each at BPBM and CTFT.

Etymology. gilvus, L., meaning pale yellow.

Discussion. Paraluma gilva can be distinguished from the remaining species of Paraluma by the characters given in the key.

Biology. Paraluma gilva was collected only from the type locality (altitude $458 \mathrm{~m}$ ). Water temperatures were $18-19^{\circ} \mathrm{C}$. Nymphs were found on and between small rocks in faster portions of the stream. Subimagos were collected after dark at light trap.

\subsection{Paraluma pulla, new species}

(Figs. 5, 25-26, 38, 59, 71-72, 104, 135)

Male imago (in alcohol)

Length : body $4.6-4.8 \mathrm{~mm}$; fore wings $5.0-5.1 \mathrm{~mm}$. Upper portion of eyes reddish-brown, lower portion black (Fig. 25-26). Head dark brown, carinae darker.
Antennae brown, flagellum paler. Thorax dark brown, mesonotum and carinae darker, sutures paler, carinae of pleura and pronotum blackish-brown. Coxae dark brown, remainder of legs pale, except prothoracic legs darker, apical margin of tibiae and tarsal segments 1-3 of mesothoracic and metathoracic legs dark brown. Wings (Fig. 5) : longitudinal veins of fore and hind wings dark brown, except veins faded in $\mathrm{CuA}$ area of fore wings and posterior half of hind wings, cross veins of hind wings faded, membrane of fore and hind wings hyaline except base of fore and hind wings brown, apical $1 / 3$ of cells $\mathrm{C}$ and Sc of fore wings translucent, whitish. Abdomen : brown, terga 1-10 washed with dark brown (Fig. 71), terga 5-7 with paired, submedian, blackish-brown, longitudinal bars extended entire length of each tergum except at anterior and posterior margins, bars faded on tergum 5 ; spiracles dark brown, tracheae hyaline ; sterna brown, anterior margin of sternum 1 darker. Genitalia (Fig. 38) : brown, apical half of forceps paler. Caudal filaments brown, darker in basal $1 / 4$.

Female imago. Unknown.

Mature nymph (in alcohol)

Head brown, venter lighter. Thorax : brown, venter paler, darker blackish-brown marks as in $\sigma^{\prime}$ imago.

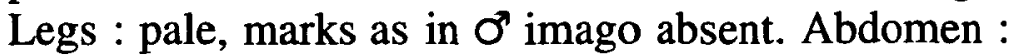
brown, venter paler, marks as in $\sigma^{\top}$ imago, except paired, submedian, longitudinal bars on terga 5-9 lighter, marks on 9 nymph similar to those on o' nymph. Gills : membrane translucent gray, tracheae black. Caudal filaments pale.

Specimens. Holotype O imago, No. N42 ; paratypes : 2 ơ, N42; 2 nymphs, No. FNK68; 2 nymphs, No. FNK82 ; 2 nymphs, No. FNK87 ; 9 nymphs, No. FNK88-89; 2 nymphs, No. FNK104. All types are in alcohol. Association of the ơ imago and nymph is by the abdominal color pattern. Type depositions : holotype and paratypes at FAMU, except : $10^{7}$ and 2 nymphal paratypes at NMNH ; 3 nymphal paratypes each at ORSTOM, CTFT, and BPBM.

Etymology. pullus, L. meaning dark colored.

Discussion. Paraluma pulla can be distinguished from the remaining species of Paraluma by characters given in the key. Although $\$$ imagos are unknown, they would be expected to have the same color pattern as $\sigma^{7}$ imagos with a total body length (head to tergum 10) of $5 \mathrm{~mm}$ or more.

Biology. Most specimens of Paraluma pulla were collected on the East Coast by Prof. Starmühlner in August and early September. Nymphs were found in streams with water temperatures of $18.6-21.7^{\circ} \mathrm{C}$ and at 
about 4-250 m. Nothing is known about the habits of the nymphs or imagos.

\subsection{Paraluma miruta, new species}

(Figs. 6, 40, 59-61, 73-74, 105 )

Male imago (in alcohol)

Length : body 3.0-3.5 mm; fore wings 4.0-4.2 mm. Upper portion of eyes reddish-brown, lower portion black. Head dark blackish-brown, carinae darker. Antennae brown, flagellum paler. Thorax dark brown, carinae darker, sutures paler, carinae of pleura heavily washed with blackish-brown, dorsum and posterior margins of scutellum blackish-brown. Coxae washed with dark brown, remainder of legs pale. Wings (Fig. 6) : longitudinal veins of fore and hind wings brown, veins faded in posterior half of fore and hind wings, cross veins of fore and hind wings hyaline ; membrane of fore and hind wings hyaline, except base of fore and hind wings light brown, apical $1 / 3$ of cells $C$ and Sc of fore wings translucent, whitish. Abdomen : light brown, terga 1-10 heavily washed with dark brown, terga 1-10 with a narrow, pale, median, longitudinal line, line faded on terga 1 and 10 , lateral to pale line, paired, anterior, small pale marks (Fig. 73), pale marks less distinct on terga 1 and 8-10, darker blackishbrown lateral and sublateral marks on terga 1-9 (Fig. 73-74) ; spiracles dark blackish-brown, tracheae hyaline ; sterna 1-8 with large, lateral, brown maculae, maculae faded on sterna 2-7, sternum 9 uniformly washed with brown. Genitalia (Fig. 40) : brown. Caudal filaments light brown.

\section{Female imago (in alcohol)}

Length : body 3.2-3.4 mm ; fore wings 4.0-4.2 mm. Eyes black. Head dark brown, carinae darker. Antennae brown, flagellum paler. Thorax : color and marks as in $\sigma^{\circ}$ imago. Wings : longitudinal veins in fore and hind wings brown, veins faded in posterior half of hind wings, cross veins in fore and hind wings hyaline, except cross veins brown in anterior $1 / 3$ of fore wings ; membrane of fore and hind wings hyaline, except base of fore and hind wings brown, apical $1 / 3$ of cells $C$ and $\mathrm{Sc}$ of fore wings translucent, whitish. Color and marks of legs as in $\sigma^{\circ}$ imago. Abdomen : color and marks as in $0^{\prime}$ imago, except area lateral to pale, median line on terga darker, lateral maculae on sterna 1-8 darker brown (Fig. 59). Caudal filaments light brown.

\section{Mature nymph (in alcohol)}

Head : brown, venter paler, dorsum washed with darker brown between eyes and ocelli. Thorax : brown, venter lighter, lateral areas of mesonotum and areas around fore wing pads washed heavily with darker brown, lateral margins of pronotum darker brown, a darker brown median mark on pronotum. Legs : color and marks as in $\sigma^{\circ}$ and $\varphi$ imagos. Abdomen : color and marks in $\sigma^{\prime}$ and $\%$ imagos, except pale median and submedian marks on terga obscured. Gills : membrane translucent gray, tracheae black. Caudal filaments light brown.

Specimens. Holotype ơ imago, No. N51 ; allotype $q$ imago, No. N51 ; paratypes : 2 nymphs, $10^{\circ}, 1$ \%, No. N26 ; 5 nymphs, 1 \&, 3 ơ subimagos, 4 \% subimagos, No. N51; 3 nymphs No. FNK72. All types are in alcohol. Association of the nymph and adults in by size and color pattern. Type depositions : holotype, allotype, and paratypes at FAMU, except : 1 nymphal paratype, $1 \sigma^{7}$ subimaginal paratype and $1 \%$ subimaginal paratype at NMNH, $1 \%$ subimaginal paratype and 1 nymphal paratype at ORSTOM, 1 nymphal paratype each at CTFT and BPBM.

\section{Etymology. minuta, L., meaning small.}

Discussion. Paraluma minuta can be distinguished from other species of Paraluma by the characters given in the key.

Biology. Paraluma minuta occurs in the Southern Region and is found in median to large sized rivers. Nymphs were found in streams with water temperatures of $19-20.5^{\circ} \mathrm{C}$ and at about $137-183 \mathrm{~m}$. It was most abundant at locality No. N51 with a water temperature of $19^{\circ} \mathrm{C}$.

Nymphs occur under small rocks along the river bank in slow moving water. Subimagos were collected at light traps, but swarming was never seen.

\subsection{Paraluma maculata, new species}

(Figs. 7-9, 39, 75-76)

\section{Male imago (in alcohol)}

Length : body $3.0-3.5 \mathrm{~mm}$; fore wings $3.6-3.7 \mathrm{~mm}$. Upper portion of eyes reddish-brown, lower portion black. Head light brown, carinae dark brown. Antennae light brown, flagellum paler. Thorax brown, carinae darker, sutures paler, carinae of pleura heavily washed with blackish-brown, margins and carinae of pronotum and dorsum of scutellum blackish-brown. Coxae light brown, irregularly washed with darker brown, remainder of legs pale. Wings (Fig. 7-9) : longitudinal veins of fore and hind wings light brown, veins faded in posterior half of wings, cross veins hyaline; membrane of fore and hind wings hyaline, except base of wings light brown and apical 1/3 of cells $C$ and $\mathrm{Sc}$ of fore wings translucent, whitish. Abdomen : light brown, tergum 1 uniformly washed with darker brown, terga 2-9 heavily washed with darker brown, median 
area of terga 4 and 5 pale (Fig. 76), tergum 10 uniformly light brown; spiracles dark brown, tracheae hyaline ; sterna uniformly light brown. Genitalia (Fig. 39) : light brown. Caudal filaments light brown.

\section{Female imago (in alcohol)}

Length : body $3.2-3.3 \mathrm{~mm}$; fore wings $3.6-4.0 \mathrm{~mm}$. Eyes black. Head light brown, carinae dark brown. Antennae light brown, flagellum paler. Thorax : color and marks as in $\sigma^{\prime}$ imago. Wings : color and marks as in $\sigma^{7}$ imago. Color and marks of legs as in $\sigma^{7}$ imago. Abdomen : color and marks as in $\sigma^{\prime}$ imago, except marks on terga darker and more distinct. Caudal filaments light brown.

\section{Mature nymph. Unknown.}

Specimens. Holotype ơ imago, No. N51; allotype $q$ imago, No. N51 ; paratypes : 1 \%, No. N26; 1 ơ, 1 \%, No. N27 ; $20^{\prime \prime}, 40^{7}$ subimagos, $110^{\prime \prime}$ subimagos, No. N51. All types are in alcohol. Association of the $\sigma^{\circ}$ and $\mathcal{Q}$ is by the abdominal color pattern. Types are deposited in the following collections : holotype, allotype, and paratypes at FAMU, except $1 \sigma^{\circ}, 1 \%$ and $2 \%$ subimaginal paratypes at ORSTOM and $1 \sigma^{\prime \prime}$ subimaginal and $2 \%$ subimaginal paratypes each at $\mathrm{NMNH}$, CTFT and BPBM.

Etymology. macula, L., meaning spot.

Discussion. Paraluma maculata can be distinguished from other species of Paraluma by characters given in the keys. Although the nymph of $P$. maculata is unknown, it would be expected to key to $P$. cancellata from which it would be distinguished by the small size of mature nymphs and the uniform color patterns similar to that illustrated for imagos (Fig. 76).

Biology. Paraluma maculata has been collected from the Southern Region. A single $\$$ from N17 not included in the type series extends the known range north to Col d'Amieu. It has been found in small streams to large rivers at altitudes of $137-412 \mathrm{~m}$. Water temperatures were $16.5-20.5^{\circ} \mathrm{C}$, but the species was most abundant at locality No. N51 with a water temperature of $19^{\circ} \mathrm{C}$. Subimagos were collected at light traps ; swarming was never observed.

\section{Oumas, new genus}

(Figs. 10-12, 27-28, 33, 41, 54, 62-63, 77-80, 95, $109-114,127-129,142-145$ )

\section{Imago}

Length of $\sigma^{\circ}$ : body $5.0-5.2 \mathrm{~mm}$; fore wings, 5.0-5.5 $\mathrm{mm}$. Length of $\$$ : body $4.0-4.5 \mathrm{~mm}$; fore wings 5.5 $\mathrm{mm}$. Eyes of $\sigma^{\prime \prime}$ separated on meson of head by a distance less than to equal maximum width of median ocellus, dorsally upper portion circular, lower portion of eyes a little more than $1 / 2$ length of upper portion (Fig. 27-28); eyes of $q$ separated on meson of head by a length 3 times as great as maximum width of an eye. Wings (Fig. 10-12) : maximum width of fore wings a little more than $1 / 3$ maximum length; vein Rs of fore wings forked less than $1 / 4$ of distance from base to margin ; vein MA forked about $1 / 2$ of distance from base to margin, fork symmetrical; vein $\mathrm{MP}_{2}$ attached at base to veins $\mathrm{MP}_{1}$ and $\mathrm{CuA}$ with a cross vein, attachment of vein $\mathrm{MP}_{2}$ to $\mathrm{MP}_{1} 1 / 3$ of distance from base to margin, base of vein $\mathrm{MP}_{2}$ equidistant between veins $\mathrm{MP}_{1}$ and $\mathrm{CuA}$; vein $\mathrm{I} \mathrm{Cu}_{1}$ attached to veins $\mathrm{CuA}$ and $\mathrm{CuP}$ with a cross vein, remainder of $\mathrm{CuA}$ area as in Fig. 10 ; cross veins few. Costal projection of hind wings well developed, rounded (Fig. 11-12), apex located $1 / 2$ distance from base ; apex of wings acute, rounded ; cross veins few. Legs : ratios of segments in O' fore legs, $0.80: 1.00(1.5 \mathrm{~mm}): 0.07: 0.33: 0.27:$ $0.20: 0.13$. Claws of a pair dissimilar, one apically hooked (Fig. 33), other obtuse, pad-like. Male genitalia (Fig. 41) : segment 2 of forceps 1-1/2 times length of segment 3, segment 2 of forceps $1 / 2$ length of segment 1 ; base of forceps broad, its inner margin forming an angular bend near basal 1/3 of forceps ; length of styliger plate along median line a little less than $1 / 3$ maximum width, apex shallowly cleft ; penes fused except for apical 1/4, apical cleft U-shaped (Fig. 41), penes broad except broader near base, apex of each penis lobe blunt. Ninth sternum of $Q$ entire apically (Fig. 54) ; sternum 7 broadly rounded (Fig. 62-63). Terminal filament a little longer than cerci.

\section{Mature nymph}

Head prognathous. Antennae longer than head (antennae of all specimens broken off distally). Mouthparts (Fig. 109-114,127-129) : dorsal hair on labrum as in Fig. 109 ; submedian and anterior areas of hair ventrally ; anteromedian margin with 4 small, blunt denticles (Fig. 110) ; labrum short, narrower than clypeus (Fig. 109). Clypeus as in Fig. 109. Left mandible as in Fig. 112 ; outer incisors serrated apically (Fig. 113). Lingua of hypopharynx with well developed lateral processes and paired, submedian, internal, longitudinal row of long hair on dorsum, anterior margin shallowly cleft, apex of submedian lobes with a rake-like process ; superlinguae as in Fig. 129 with a row of hair along anterior margin, lateral margins rounded. Segment 2 of maxillary palpi a little longer than length of segment 1 ; segment 3 of palpi $3 / 4$ length of segment 2 , triangular ; a V-shaped ridge near the ventral, inner anterolateral margin of maxillae; hair on maxillae as in Fig. 114. Labium as in Fig. 127 ; segment 2 of palpi 3/4 
length of segment 1 ; segment 3 of palpi $3 / 4$ length of segment 2, triangular ; paraglossae ventral to glossae, anteromedian apex of glossae knob-like. Sparse, short, fine hair on anterolateral corners of pronotum. Legs (Fig. 142-144) : maximum width of tibiae 2 times maximum width of tarsi, tibiae in cross section slightly flattened ; femora enlarged distally and dorsally so tibiae can draw completely underneath femora (Fig. 142 ) ; apex of claws hooked and narrow, denticles on claws near equal sized (Fig. 144). Gills (Fig. 145) : gills on segments 1-7 alike ; gills deeply forked, each portion long, tapered to apex ; main trunk of tracheae forked near base of gills and each branch thick and along median line of each portion of lamellae, main truck darkly pigmented, lamellae translucent. Posterolateral spines on abdominal segments 2-9, spines progressively larger posteriorly, posterolateral spine on segment 9 broad at apex (similar to Fig. 139). Terminal filament a little longer than cerci.

Etymology. Oumas, based on the name Tribu des Oumas. Masculine.

Type species. Oumas orbis, new species.

Discussion. Oumas can be distinguished from all genera of the Atalophlebiinae by the following combination of characters. In the imagos : (1) the $\mathrm{CuA}$ area of the fore wings possesses 2 long intercalaries (Fig. 10) and vein MA is forked symmetrically ; (2) length of vein Sc of the hind wings is about 3/5 maximum length of hind wings (Fig. 11-12); (3) claws of a pair are dissimilar ; one is apically hooked while other is obtuse, pad-like (Fig. 33) ; (4) penes of O' genitalia are broad and fused except for apical 1/4; no dorsal spines occur on penis lobes (Fig. 41) ; (5) segment 2 of forceps of $\sigma^{7}$ genitalia is about $1 / 2$ length of segment 1 (Fig. 41) ; and (6) the ninth sternum of $q$ is entire apically (Fig. 54). In the nymphs : (1) apex of submedian lobes of lingua each possess a rake-like process (Fig. 129 ) ; (2) length of segment 3 of labial palpi is $3 / 4$ length of segment 2 (Fig. 127) ; (3) outer margin of mandibles is curved as in Fig. 112 and outer incisors are serrated (Fig. 113) ; (4) denticles on claws are nearly equal-sized (Fig. 144); and (5) the labrum is small, much shorter and narrower than the clypeus, and lacks any anteromedian emargination or cleft (Fig. 109110).

Oumas appears to be most closely related to Paralu$m a$ and can be distinguished from Paraluma by the following characters. In the imagos : (1) segment 2 of forceps is about 1/2 length of segment 1 (Fig. 41) and (2) penes of $O^{7}$ genitalia are broad and fused except for apical $1 / 4$; no spines occur on penis lobes (Fig. 41). In the nymphs : (1) denticles on claws are nearly equal-si- zed (Fig. 144) and (2) the labrum is small, shorter and narrower than the clypeus, and lacks any anteromedian emargination or cleft (Fig. 109-110).

\subsection{Oumas orbis, new species}

(Figs. 10-12, 27-28, 33, 41, 54, 62-63, 77-80, 95, $109-114,127-129,142-145$ )

\section{Male imago (in alcohol)}

Length : body $5.0-5.2 \mathrm{~mm}$; fore wings $5.0-5.5 \mathrm{~mm}$. Upper portion of eyes reddish-brown, lower portion black (Fig. 27). Head tan, carinae and anterior margin blackish-brown. Antennae tan. Thorax tan, pleura and venter paler, lateral margins of pronotum lightly washed with blackish-brown, a wide, blackish-brown bar extended between base of wings to base of legs on mesopleuron and metapleuron. Coxae tan, washed heavily with blackish-brown, remainder of legs pale, except apex of femora with a wide, transverse, dark brown band, apex of prothoracic tibiae dark brown. Wings (Fig. 10-12): longitudinal veins of fore and hind wings tan, veins faded in CuA area of fore wings and posterior half of hind wings, cross veins of fore and hind wings light tan, veins faded in posterior half of fore and hind wings ; membrane hyaline, light tan, except apical $1 / 3$ of cells $C$ and Sc of fore wings translucent, whitish. Abdomen (Fig. 79-80) : segments 1-6 translucent, lightly washed with light tan, segments 7-10 opaque, tan ; posterior margin of terga 2-6 with a narrow, transverse, blackish-brown band, band faded on tergum 6 , terga 7 and 8 washed with darker tan as in Fig. 79, terga 9 and 10 uniformly washed with darker tan ; spiracles blackish-brown, tracheae hyaline, except edges washed lightly with blackish-brown. Genitalia (Fig. 41) : tan. Caudal filaments pale, articulations in basal half a little darker.

\section{Female imago (in alcohol)}

Length : body $4.0-4.5 \mathrm{~mm}$; fore wings $5.5 \mathrm{~mm}$. Eyes black. Head : color and marks as in ơ imago. Antennae $\tan$. Thorax : color and marks as in $\sigma^{\prime}$, except areas around tergal carinae washed with blackish-brown. Legs : tan, femora with a wide, apical, transverse, blackish-brown band (Fig. 77). Wings : color and marks as in $\sigma^{\top}$ imago. Abdomen : tan, brown to blackish-brown marks on terga 4-7 as in Fig. 78, dark markings heaviest on terga 3 and 6 ; terga 4-5 and 7-9 less extensively marked. Caudal filaments ; color and marks as in ơ imagos.

\section{Mature nymph (in alcohol) (Fig. 95)}

Head : light brown, venter paler, darker blackishbrown marks as in $\sigma^{\circ}$ and $\%$ imagos. Thorax : light brown, venter paler, darker blackish-brown marks as 
in $\sigma^{\prime}$ and $\$$ imagos. Legs : pale, tarsi darker, marks as in $\sigma^{\prime \prime}$ and $\$$ imagos absent. Abdomen : color and marks as in $\sigma^{\prime \prime}$ and $\%$ imagos. Gills (Fig. 145) : membrane translucent, gray, tracheae black. Caudal filaments pale.

Specimens. Holotype ơ. imago, No. N42 ; allotype 9 imago, No. N37 ; paratypes : $30^{\circ}, 1$ \%, 1 \% subimago, No. N42; 1 nymph, 1 o' subimago, No. N43; 1 nymph, No. FNK4 ; 1 nymph, No. FNK23-24 ; 7 nymphs, No. FNK55 ; 1 nymph, No. FNK63 ; 1 nymph, No. FNK68 ; 2 nymphs, No. FNK79 ; 3 nymphs, No. FNK82 ; 2 nymphs, No. FNK84; 8 nymphs, No. FNK94. All types are in alcohol. Association of the nymph and male imago is by rearing, and the female imago is associated by the developing color pattern. Type depositions : holotype, allotype, and paratypes at FAMU, except : $10^{\circ}$ and 4 nymphal paratypes each at NMNH and ORSTOM, and 5 nymphal paratypes each at CTFT and BPBM. Terga 4 and 5 of the female from locality No. 42 are less extensively marked than the terga of the allotype specimen illustrated from locality No. N37.

Etymology. orbis, L., meaning ring.

Biology. Oumas orbis occurs throughout New Caledonia. Nymphs were found in streams with water temperatures of $15.2-24^{\circ} \mathrm{C}$ and at about $76-350 \mathrm{~m}$. The species was rare at all localities ; however, most specimens were collected in streams with water temperatures of $18-19^{\circ} \mathrm{C}$. Nothing is known about the habits of the imagos or nymph.

\section{Amoa, new genus}

(Figs. 13-22, 29-31, 34, 42-45, 55-56, 64-67, 81-93, 96-97, 115-123, 130-134, 146-156)

\section{Imago}

Length of $\sigma^{\prime \prime}$ : body $4.3-6.0 \mathrm{~mm}$; fore wings $4.4-6.0$ $\mathrm{mm}$. Length of $Q$ : body $5.0-5.2 \mathrm{~mm}$; fore wings $5.6-$ $6.3 \mathrm{~mm}$. Eyes of $\sigma^{\prime}$ separated on meson of head by a distance 1 to $1-1 / 2$ times width of a lateral ocellus (Fig. 30-31), dorsally upper portion oval to subcircular, lower portion less than $1 / 2$ to $3 / 4$ length of upper portion (Fig. 29) ; eyes of 9 separated on meson of head by a distance 4 times maximum width of an eye. Wings (Fig. 13-22) : maximum width of fore wings $1 / 3$ to a little more than $1 / 3$ maximum length ; vein Rs of fore wings forked $1 / 4$ to a little more than $1 / 4$ of distance from base to margin ; vein MA forked about $1 / 2$ distance from base to margin, fork symmetrical ; vein MP2 attached at base to vein MP ${ }_{1}$ and $\mathrm{CuA}$ with a cross vein, attachment of vein $\mathrm{MP}_{2}$ to $\mathrm{MP}_{1} 1 / 3$ to a little more than $1 / 2$ of distance from base to margin, base of vein $\mathrm{MP}_{2}$ equidistant between veins $\mathrm{MP}_{1}$ and $\mathrm{CuA}$ to nearer to $\mathrm{MP}_{1}$; vein $\mathrm{ICu}_{1}$ attached to veins $\mathrm{CuA}$ and $\mathrm{CuP}$ with a cross vein, remainder of $\mathrm{CuA}$ area as in Fig. 13, 16, 19 ; cross veins few. Costal projection of hind wings well developed, rounded (Fig. 14-15, 17$18,21-22$ ), apex located less than $1 / 2$ to $1 / 2$ distance from base ; apex of wings acute, rounded ; cross veins few. Legs : ratios of segments in ơ fore legs, $0.64-0.65$ : $1.00(2.0-2.2 \mathrm{~mm}): 0.05: 0.35-0.50: 0.30-0.41$ : $0.25-0.28: 0.14-0.15$. Claws of a pair dissimilar, one apically hooked (Fig. 34), other obtuse, pad-like. Male genitalia (Fig. 42-45) : segment 2 of forceps a little longer than segment 3 , segment 2 of forceps $1 / 6$ to $1 / 5$ length of segment 1 ; base of forceps broad, its inner margin forming an angular bend near middle of forceps ; length of styliger plate along median line less than $1 / 2$ to $1 / 2$ maximum width, apex smooth to shallowly cleft ; penes broad, flattened, lateral margins tapered towards apex, fused except at apex, sometimes with a median, raised line extended almost entire length of penes (Fig. 44). Ninth sternum of $\%$ entire to shallowly cleft apically (Fig. 55-56) ; sternum 7 broadly rounded, extended posteriorly (Fig. 64-67) (see discussion). Terminal filament a little longer than cerci.

\section{Mature nymph}

Head prognathous. Antennae 1-1/2 to $2-1 / 2$ times maximum length of head. Mouthparts (Fig. 115-123, 130-134) : dorsal hair on labrum as in Fig. 115, 120 ; submedian and anterior areas of hair ventrally ; anterior margin with deep anteromedian emargination with 5 large, rounded denticles (Fig. 116, 121). Clypeus as in Fig. 115, 120. Left mandible as in Fig. 117, 122. Lingua of hypopharynx with well developed lateral processes and paired, submedian, internal longitudinal row of long hair on dorsum, anterior margin cleft, apex of submedian lobes with a rake-like process ; superlinguae as in Fig. 131, with a row of hair along anterior margin, lateral margins blunt. Segment 2 of maxillary palpi equal to a little longer than length of segment 1 ; segment 3 of palpi more than $1 / 2$ to subequal length of segment 2, triangular ; a V-shaped ridge near the ventral, inner anterolateral margin of maxillae ; hair on maxillae as in Fig. 119, 123. Labium as in Fig. 130, 132-134; segment 2 of palpi equal to a little longer in length than segment 1 ; segment 3 of palpi $2 / 3$ to subequal length of segment 2 ; paraglossae ventral to glossae. Sparse, long, fine hair on entire head and body. Legs (Fig. 146-150) : outer margin of femora indented near apex so tibiae can draw partially into femora ; maximum width of tibiae 2 times maximum width of tarsi, tibiae in cross section somewhat triangular (Fig. 147), apex of tibiae with pectinate setae (Fig. 148- 
149); apex of claws hooked and narrow, denticles on claws progressively larger apically (Fig. 150). Gills (Fig. 151-153) : gills on segment 1-7 alike ; gills deeply forked and 2 portions of lamellae overlap on dorsal surface, each portion long, broad basally and abruptly tapered to apex ; main trunk of tracheae forked near base of gills and each branch along median line of each portion of lamellae, main trunk darkly pigmented, a few, fine black tracheal branches present (Fig. 152) or absent (Fig. 151), both portions of lamellae translucent. Posterolateral spines on abdominal segments 2 to 6-9, spines progressively larger posteriorly, apex of posterolateral spines on segment 8-9 (Fig. 154) or segment 9 only $(A$. orthogonia) indented giving appearance of double spines. Terminal filament a little longer than cerci.

Etymology. Amoa, based on the name Tribu d'Amoa. Feminine.

\section{Type species. Amoa fronini, new species.}

Discussion. Amoa can be distinguished from all genera of the Atalophlebiinae by the following combination of characters. In the imagos : (1) the CuA area of the fore wings possesses 2 long intercalaries (Fig. 13, $16,19)$ and vein MA is forked symmetrically ; (2) length of vein $\mathrm{Sc}$ of the hind wings is $1 / 2$ to $2 / 3$ maximum length of hind wings (Fig. 15, 18, 22 ) ; (3) claws of a pair are dissimilar ; one is apically hooked while other is obtuse, pad-like (Fig. 34) ; (4) penes of $0^{7}$ genitalia are fused except at extreme apex (Fig. 42-45) ; and (5) sternum 7 of female is broadly expanded (Fig. 64-67). In the nymph : (1) anterior margin of lingua of hypopharynx is cleft ; apex of submedian lobes of lingua each possess a rake-like process (Fig. 131) ; (2) maximum length of segment 3 of labial palpi is $2 / 3$ to subequal length of segment 2 (Fig. 131-134) ; (3) outer margin of mandibles is smoothly curved and a tuft of hair occurs near the middle of the outer margin (Fig. $117,122)$; (4) apex of tibiae possesses pectinate setae (Fig. 148-149); and (5) anteromedian emargination of labrum possesses 5 large, equal-sized, rounded denticles (Fig. 115-116, 120-121).

Within New Caledonia, Amoa appears to be most closely related to Paraluma but can be distinguished from it by the following combination of characters. In the imagos : (1) penes of $\sigma^{\circ}$ genitalia are apically acute and fused except at extreme apex (Fig. 42-45) ; and (2) forceps of $\sigma^{\prime}$ genitalia are relatively straight (Fig. 4245). In the nymph : (1) anteromedian emargination of labrum possesses 5 large and equal-sized denticles (Fig. 115-116, 120-121) ; (2) lateral margins of labrum are rounded (Fig. 115, 120) ; (3) large pectinate setae are present on apex of fore tibiae (Fig. 148-149) ; and
(3) each portion of abdominal gills 1-7 is long, broad basally and abruptly tapered to apex (Fig. 151-153).

In females of Amoa, lateral oviducts meet in the posterior third of sternum 7, and it appears that eggs are extruded from a single expanded opening encompassing both oviducts.

Three species of Amoa (A. cressonensis sp.n., A. hebes sp.n., and $A$. orthogonia sp.n.) are distinct in color and morphology. The remaining specimens display a variable color pattern. Although these color differences appear consistent between localities for Amoa, no locality is represented by more than two male imagos. Therefore, specimens from the Ile des Pins are treated as a separate species because of additional differences in genital morphology, and the remaining specimens from New Caledonia are treated as subspecies. Further study may reveal that these subspecies are nothing more than locality variants.

\section{Keys to the Species of Amoa, new genus MALE IMAGOS}

1. Terga 2-6 translucent, lightly washed with brown ; tergum 7 with darker brown rectangular marks as in Fig. 91 ; distinct black marks present in costal brace and base of fore wings (Fig. 20) ; margins of basal half of penes parallel (Fig. 45) .................................................... A. orthogonia

-- Terga 2-6 washed with dark brown (Fig. 81-90) ; tergum 7 without rectangular marks ; costal brace and base of fore wings without distinct marks ; margins of basal half of penes tapered apically (Fig. 42-44)

2. Metathoracic femora washed heavily with dark brown ; caudal filaments brown; penes entirely fused (Fig. 44) A. hebes

-- Metathoracic femora pale ; caudal filaments light brown with darker brown, narrow annulations at least in basal half ; penes with small cleft at apex (Fig. 42-43) ........... 3

3. Penes of $O^{7}$ genitalia with very small spines at apex (Fig. 42A) ; terga 2-6 washed with blackish-brown except for large, median, pale area as in Fig. 81 ; Île des Pins A. fronini

-- Penes of $\sigma^{\prime \prime}$ genitalia as in Fig. 43 with few or no spines (Fig. 43A), not as above ; terga 2-6 variable, blackishbrown with large to small pale, anteromedian area (Fig. $84,86)$; main island of New Caledonia ....... A. subsolana

\section{MATURE NYMPHS}

1. Posterolateral spines on abdominal terga 6-9, those on terga 6-7 very small, not always evident (Fig. 156) ; segment 3 of maxillary palpi a little more than $1 / 2$ length of segment 2 (Fig. 123); $\sigma^{\prime}$ and $Q$ nymphs with color pattern of imagos (Fig. 91-93, 97) ........................... A. orthogonia

-- Posterolateral spines on 2 to 4-9, conspicuous on terga 6-9 (Fig. 155) ; segment 3 of maxillary palpi $7 / 8$ to subequal length of segment 2 (Fig. 119); color patterns not as above. 
2. Mesothoracic coxae light brown with small blackishbrown maculae ; color pattern of ơ nymph with pale median area on terga 4-5 and anterior tergum 6 (Fig. 90); segment 3 of labial palpi with $\geq 12$ dorsal spines (Fig. 134); gill membrane broad for more than half length of gill, sometimes with fine tracheal branches on ventral portion (Fig. 152) ; known only from northern New Caledonia A. cressonensis

-- Mesothoracic coxae washed with blackish-brown ; abdomen blackish-brown (Fig. 96) ; abdominal pattern of preemergent nymphs similar to imagos as in Fig. 81-89; segment 3 of labial palpi with 6-9 dorsal spines (Fig. 130, 132) ; gill membrane not as above, with tracheal trunk only (Fig. 151) ; generally distributed

\section{3}

3. Color pattern of mature on nymphs with pale median area on terga 4-6 similar to that of imagos (Fig. 81) ; Île des Pins A. fronini

-- Color pattern of $\sigma^{\prime \prime}$ nymphs variable, with or without pale median area on terga 4-6, similar to pattern of imagos (Fig. 84-87, 96) ; main island of New Caledonia A. subsolana

\subsection{Amoa fronini, new species}

(Figs. 13-15, 29-30, 34, 42, 55, 64-65, 81-83, 115$119,130-131,146,148-151,154-155)$

\section{Male imago (in alcohol)}

Length : body 4.5-5.6 mm ; fore wings $5.0-6.0 \mathrm{~mm}$. Upper portion of eyes reddish-brown, lower portion black (Fig. 29-30). Head brown, carinae darker, area around base of eyes dark brown. Antennae light brown. Thorax dark brown, pleura paler, carinae darker, sutures paler, areas around base of legs and wings washed heavily with blackish-brown, margins and carinae of pronotum washed heavily with blackishbrown, mesobasisternum washed with blackishbrown. Coxae blackish-brown, remainder of legs pale, except apex of tarsal segments darker, prothoracic femora darker, carinae near middle of prothoracic femora dark brown. Wings (Fig. 13-15) : longitudinal veins of fore and hind wings light brown, cross veins of fore and hind wings hyaline, except those in anterior half of fore wings a little darker ; membrane hyaline, except base of fore and hind wings light brown, apical $1 / 3$ of cells $\mathrm{C}$ and $\mathrm{Sc}$ of fore wings translucent, whitish. Abdomen : brown, terga 1-10 washed with darker brown, posterior margin of terga 1-8 with a narrow, dark blackish-brown, transverse band ; terga 6-9 with a narrow, pale, median, longitudinal line extended entire length of each tergum, line faded on terga 8 and 9 ; pale, anterior, triangular area on dorsum of terga 3-6, smaller on terga 3 and 6 (Fig. 81) ; lateral margins of terga 2-9 paler as in Fig. 82 ; spiracles dark brown, tracheae washed heavily with dark brown; sterna $2-7$ with small, dark brown maculae on posterolateral margins, sterna 8 and 9 washed lightly with darker brown. Genitalia (Fig. 42) : brown, forceps paler apically, small spines at apex of each penis lobe (Fig. 42A). Caudal filaments brown with darker brown, narrow annulations at articulations in basal half, sometimes only at alternate articulations.

\section{Female imago (in alcohol)}

Length : body 4.7-5.2 $\mathrm{mm}$; fore wings $5.6-6.1 \mathrm{~mm}$. Eyes black. Head brown washed with blackish-brown, carinae darker. Antennae light brown. Thorax : color and marks as in $\sigma^{\top}$ imago. Color and marks of legs as in $\sigma^{*}$ imago, except prothoracic femora a little darker. Wings as in $0^{7}$ imago except longitudinal veins in fore and hind wings brown, cross veins in fore and hind wings light brown. Abdomen : color and marks as on segments 7-9 of $\sigma^{\circ}$ imago, terga blackish-brown with small anterior and anterosubmedian pale areas (Fig. 83), lateral margins of sterna 1-7 washed lightly with darker brown, reduced on sternum 7 (Fig.64). Caudal filaments : color and marks as in $0^{7}$ imago.

\section{Mature nymph (in alcohol)}

Head : light brown, venter paler, dorsum washed heavily with darker brown between eyes, ocelli, and antennae. Thorax : brown, venter lighter, lateral areas of mesonotum and areas around fore wing pads washed heavily with darker brown, lateral margins of pronotum darker brown, darker brown median mark on pronotum. Legs : color and marks as in $\sigma^{\circ}$ and $\$$ imagos, except marks paler (Fig. 146). Abdomen : color and marks as in $0^{\circ}$ and $O$ imagos, except pale anterior marks on terga obscured, median line most evident on terga 6-9, sterna 8 and 9 paler. Posterolateral spines on abdominal terga 3 to 4-9. Gills (Fig. 151) : membrane gray, tracheae black, tracheal branches absent. Caudal filaments brown, marks as in $\sigma^{7}$ and $\%$ imagos.

Specimens. Holotype $\sigma^{\prime}$ imago, No. N31 ; allotype $q$ imago, No. N31 ; paratypes : 5 nymphs, $10^{7}, 4 \%, 2$ 웅 subimagos, No. N31; 2 nymphs, 1 \%, No. N33 ; 9 nymphs, No FNK113; 3 nymphs, No. FNK114; 5 nymphs, No. FNK115. All types are in alcohol. Association of the nymph and adults is by the abdominal color pattern. Type depositions : holotype, allotype, and paratypes at FAMU, except : $1 \%$ and 3 nymphal paratypes each at BPBM, ORSTOM, CTFT, and NMNH. Additional material : $20^{\prime \prime}$ from spider webs and young nymphs from above localities and FNK116.

Etymology. Species is named in honor of Mr. Janick Fronin, Eaux et Forêts, Station Forestière, Kuto, Île des Pins. 
Discussion. Amoa fronini can be distinguished from the remaining species of Amoa by characters given in the keys. Nymphs of $A$. fronini are distinguished from those of $A$. subsolana by locality.

Biology. Amoa fronini occurs throughout the Île des Pins, and water temperatures where collected were $20.5-27^{\circ} \mathrm{C}$. Nymphs occur on small rocks to rubble in the slower portions of the streams. Some imagos were collected swarming over the stream between 1200 and $1600 \mathrm{~h}$.

\subsection{Amoa subsolana, new species}

(Figs. 43, 84-87, 96, 132, 147)

\section{Male imago (in alcohol)}

Length : body 4.3-5.6 $\mathrm{mm}$; fore wings $4.6-6.0 \mathrm{~mm}$. Upper portion of eyes reddish-brown, lower portion black. Head brown, carinae darker. Antennae light brown, flagellum paler. Thorax dark brown, pleura paler, carinae darker, sutures paler, areas around base of legs and wings washed heavily with blackish-brown, margins and carinae of pronotum washed heavily with blackish-brown, mesobasisternum washed with blackish-brown. Coxae blackish-brown, remainder of legs pale, except apex of tarsal segments darker, prothoracic legs darker, carinae near middle of prothoracic femora dark brown. Wings : longitudinal veins of fore and hind wings light brown, faded in posterior half of fore and hind wings, cross veins of fore and hind wings hyaline, except those in anterior $1 / 3$ of fore wings a little darker ; membrane hyaline, except base of fore and hind wings light brown, apical $1 / 3$ of cells $C$ and Sc of fore wings translucent, whitish. Abdomen : brown, terga 1-10 washed with darker brown, posterior margin of terga 1-8 with a narrow, darker blackishbrown, transverse band, terga 1 and 8-10 washed uniformly with darker brown, terga 2-7 with a narrow, pale, median, longitudinal line extended entire length of each tergum, line faded on terga 2 and 7, lateral to pale line, large to small paired, triangular, pale anterior marks on terga 2-7 (Fig. 84, 86), those on terga 2 and 6-7 smaller, lateral margins of terga 2-9 pale as in Fig. 85,87 ; spiracles dark blackish-brown, tracheae washed heavily with light blackish-brown ; lateral margins of sterna 1-9 with blackish-brown maculae, faded near anterolateral corners, remainder of sterna 8 and 9 washed lightly with brown. Genitalia (Fig. 43) : brown, forceps paler apically. Caudal filaments brown with darker brown, narrow annulations at articulations in basal half, sometimes only at alternate articulations.

\section{Female imago}

Described under subspecies Amoa subsolana caerulea.

\section{Mature nymph (in alcohol)}

Head : light brown, venter paler, dorsum washed heavily with darker brown between eyes, ocelli, and antennae as in Fig. 96. Thorax : brown, venter lighter, lateral areas of mesonotum and areas around fore wing pads washed heavily with darker brown, lateral margins of pronotum darker brown, a darker brown submedian mark on pronotum as in Fig. 96. Legs : color and marks as in $\sigma^{7}$ imago, except color and marks of prothoracic legs paler. Abdomen : color and marks as in $\sigma^{\top}$ imago, except pale median and submedian marks on terga obscured, median line most evident on terga 6-9, sterna 8 and 9 paler. Posterolateral spines on abdominal terga 3 to 5-9. Gills : membrane gray, tracheae black, tracheal branches absent. Caudal filaments brown, marks as in $\sigma^{\top}$ imagos.

Etymology. subsolanus, L., meaning eastern.

Discussion. Amoa subsolana can be distinguished from the remaining species of Amoa by characters given in the keys. Amoa subsolana appears to be polytypic based on a limited number of $\sigma^{7}$ imagos ; more extensive collecting may show these to be only local variants. A. subsolana subsolana is known from the mountains of the East Coast and West Coast and $A$. subsolana caerulea is known from the Southern Region. A single $\sigma^{\prime}$ imago from N13 is intermediate in color pattern and presently considered an intergrade. Three nymphs are also present from N13.

\subsubsection{Amoa subsolana subsolana, new subspecies}

(Figs. 43, 84-85, 132, 147)

Male imago (in alcohol)

Length : body 4.3-5.6 mm ; fore wings 4.6-6.0 mm. With characters of the species. Abdominal terga 3-6 with pale anterior median and anterosubmedian maculae (Fig. 84-85).

Female imago. Unknown.

Nymph. With characters of species:

Specimens. Holotype ơ imago, No. N37 ; paratypes : 1 nymph, 3 o' subimagos, No. N17; 1 nymph, $10^{\prime \prime}$, No. N21 ; 7 nymphs, No. N37, 10 nymphs, No. FNK35; 9 nymphs, No. FNK37; 7 nymphs, No. FNK64; 5 nymphs, No. FNK 120; 7 nymphs, No. FNK121. All types are in alcohol. Association of the nymph and $\sigma^{\prime \prime}$ imago is by rearing. Type depositions : holotype and paratypes at FAMU, except : 10 ' subimaginal paratype and 8 nymphal paratypes each at NMNH and ORSTOM ; 8 nymphal paratypes each at BPBM and CTFT.

Discussion. A. subsolana subsolana can be distinguished from $A$. subsolana caerulea by the tergal color pattern of $O^{3}$ imagos (Fig. 84). 
Biology. A. subsolana subsolana occurs in streams on the East Coast and West Coast from $15-458 \mathrm{~m}$ in altitude with water temperatures of $15.2-19^{\circ} \mathrm{C}$. Subimagos were collected at light traps, but swarming was never seen.

\subsubsection{Amoa subsolana caerulea, new subspecies}

(Figs. 86-87, 96)

Male imago (in alcohol)

Length : body 4.3-4.6 $\mathrm{mm}$; fore wings $4.6-5.0 \mathrm{~mm}$. Abdominal terga 3-6 with pale median area, pale area smaller on terga 3 and 6 (Fig. 86-87).

Female imago (in alcohol)

Length : body 4.2-4.6 $\mathrm{mm}$; fore wings 4.8-5.2 $\mathrm{mm}$. Eyes black. Head brown washed with blackish-brown, carinae darker. Antennae light brown. Thorax : color and marks as in $0^{7}$ imago, except blackish-wash on mesobasisternum more extensive. Color and marks of legs as in $\sigma^{\prime}$ imago, except prothoracic femora a little darker. Wings as in $\sigma^{\prime}$ imago. Abdomen : color and marks as on segments 7-9 of $\sigma^{\circ}$ imago, terga blackishbrown with small anterior and anterosubmedian pale areas, posterolateral margins of sterna 1-7 as in $0^{7}$ but reduced on sternum 7 . Caudal filaments : color and marks as in $0^{7}$ imago.

Mature nymph (in alcohol)

With characters of species (Fig. 96).

Specimens. Holotype ơ imago, No. N50; allotype + imago, No. N51 ; paratypes : 1 nymph, No. N25; 1 O', No. N26; 11 nymphs, No. N27 ; 1 \%, 2 subimagos, No. N51 ; 8 nymphs, No. FNK57. All types are in alcohol. Association of the nymph and imago is by developing color pattern. Type depositions : holotype, allotype, and paratypes at FAMU, except : $1 \%$ subimaginal paratype and 2 nymphal paratypes each at NMNH and ORSTOM ; 3 nymphal paratypes each at BPBM and CTFT.

Etymology. caeruleus, L., meaning blue, in reference to the type locality, a tributary of the Rivière Bleue.

Discussion. A. subsolana caerulea can be distinguished from $A$. subsolana subsolana by the color pattern of $0^{\prime}$ imagos (Fig. 86-87). There is no way to distinguish female imagos or nymphs to subspecies except by association with males.

Biology. A. subsolana caerulea has been collected from streams of the Southern Region. Nymphs were collected from streams at about 100-190 m with water temperatures of $19-20.5^{\circ} \mathrm{C}$.

\subsection{Amoa hebes, new species}

(Figs. 16-18, 44)

Male imago (in alcohol)

Length : body $4.3 \mathrm{~mm}$; fore wings $4.4 \mathrm{~mm}$. Upper portion of eyes reddish-brown, lower portion black. Head dark brown, carinae blackish-brown. Scape and pedicel dark brown, flagellum broken off and missing. Thorax dark brown, pleura paler, carinae darker, sutures paler, areas around base of legs and wings washed heavily with darker brown, margins and carinae of pronotum washed heavily with blackish-brown. Coxae dark brown, trochanters pale washed heavily with darker brown, metathoracic femora and tibiae washed heavily with dark brown, except apex of tibiae and tarsi pale ; prothoracic and mesothoracic legs broken off and missing. Wings (Fig. 16-18) : longitudinal veins of fore and hind wings light brown, cross veins of fore and hind wings pale brown, faded in posterior half of fore and hind wings ; membrane hyaline, except base of fore and hind wings light brown. Abdomen : light brown, terga 2-9 washed heavily with dark brown (Fig. 88) ; spiracles dark blackish-brown, tracheae hyaline ; sternum 1 washed uniformly and lightly with dark brown, sterna 2-9 washed lightly with dark brown (Fig. 89). Genitalia (Fig. 44) : brown, apical 1/3 of segment 1 of forceps darker, segments 2 and 3 of forceps paler. Caudal filaments brown.

Female imago. Unknown.

Mature nymph. Unknown.

Specimens. Holotype $\sigma^{\prime}$ imago, No. N27. Holotype is in alcohol and deposited at FAMU.

Etymology. hebes, L., meaning blunt.

Discussion: Amoa hebes can be distinguished from the remaining species of Amoa by characters given in the key to male imagos.

Biology. Amoa hebes has been collected only from locality No. N27, altitude $153 \mathrm{~m}$. The water temperature was $19.5^{\circ} \mathrm{C}$.

\subsection{Amoa cressonensis, new species}

(Figs. 90, 134, 152)

Male imago. Unknown.

Female imago. Unknown.

Mature nymph (in alcohol)

Head : light brown, dorsum washed heavily with darker brown between eyes, ocelli, and antennae. Thorax : light brown, sterna paler ; lateral areas of mesonotum and areas around fore wing pads washed heavily with darker brown, lateral margins of pronotum dar- 
ker brown, a darker brown median mark on pronotum. Legs : light brown ; ventral surface of prothoracic femora with a large, median darker brown macula. Abdomen : light brown ; terga 1-10 of . 9 washed heavily with darker brown, except lateral margins paler, terga 5-10 with a narrow, pale, median, longitudinal line extended entire length of each tergum ; terga 1-3 of $\sigma^{\text {* }}$ heavily washed with darker brown, terga 4-10 washed heavily with dark brown as in Fig. 90. Gills (Fig. 152) : membrane gray ; tracheae black, a few fine unbranched, black tracheal branches sometimes present on ventral portion. Posterolateral spines on abdominal terga 2 to 4-9. Caudal filaments light brown.

Specimens. Holotype ơ nymph, No. FNK110 ; paratypes : 31 nymphs, No. FNK110. All types are in alcohol. Type depositions : holotype and paratypes at FAMU, except : 4 nymphal paratypes each at BPBM, ORSTOM, CTFT, and NMNH.

Etymology. Species is named for the type locality Le Cresson.

Discussion. Amoa cressonensis can be distinguished from the remaining species of Amoa by the characters in the nymphal key, although we recommend caution in using the character of enlarged gills because of the unique habitat ("mare dans un ruisseau desséché") of this species. Low oxygen habitats have been known to be associated with enlarged gills in other species (Pescador and Rasmussen 1995).

Biology. Amoa cressonensis is known only from the type locality near Le Cresson in northwestern New Caledonia. Water temperature was $19.5^{\circ} \mathrm{C}$ when collected.

\subsection{Amoa orthogonia, new species}

(Figs. 19-22, 31, 45, 56, 66-67, 91-93, 97, 120-123, $133,153,156)$

\section{Male imago (in alcohol)}

Length : body 5.7-6.0 $\mathrm{mm}$; fore wings $6.0-6.3 \mathrm{~mm}$. Upper portion of eyes reddish-brown, lower portion black (Fig. 31). Head light brown, vertex dark brown. Antennae light brown. Thorax light brown, pleura paler, carinae darker, sutures paler, margins and median carina of pronotum blackish, posterior margin of mesoscutellum blackish, areas around base of wings and legs blackish, apical $1 / 3$ of mesobasisternum and posterolateral areas of mesofurcasternum washed heavily with black. Coxae light brown, washed heavily with black, remainder of legs pale, except apex of femora with a brown band, apex of prothoracic tibiae darker brown. Wings (Fig. 19-22) : longitudinal veins of fore and hind wings light brown, veins faded in $\mathrm{CuA}$ area of fore wings and posterior half of hind wings, base of veins $C, S c$ and $R_{1}$ of hind wings blackish, veins and adjacent membrane within costal brace region of fore wings with blackish marks (Fig. 20), cross veins of fore and hind wings lighter brown, veins faded in posterior half of fore and hind wings ; membrane hyaline, light brown, except apical 1/3 of cells $\mathrm{C}$ and Sc of fore wings translucent, brownish-white. Abdomen : segments 1-7 translucent, lightly washed with light brown, segments 8-10 opaque, brown ; anterior and lateral margins of tergum 1 washed with black, posterolateral margin of terga 2-7 with blackish marks (Fig. 92), terga 7 with dark brown rectangular marks (Fig. 91), similar marks present on terga 8-9 but lighter ; tergum 10 pale with black posterior margin ; spiracles and tracheae hyaline; sternum 1 lightly washed with darker brown along anterolateral margins, sternum 9 with faint darker brown triangular mark. Genitalia (Fig. 45) : brown, forceps paler. Caudal filaments pale, basal half with wide, dark brown, annulations at alternate articulations, apical half with narrow, dark brown annulations at articulations.

\section{Female imago (in alcohol)}

Length : body $4.9-5.0 \mathrm{~mm}$; fore wings $6.2-6.5 \mathrm{~mm}$. Eyes black. Head cream-colored with dark brown mark on posteromedian margin. Antennae light brown. Thorax : color and marks as in $0^{7}$ imago. Legs as in $0^{7}$ imago, except transverse band on apex of femora pale reddish-brown and tibiae of fore legs without marks. Wings : color and marks as in $\sigma$ imago. Abdomen : base color hyaline-cream, terga 1-3 with solid dark brown marks extended over dorsal surface except for narrow median line, marks a little paler laterally as figured for tergum 4 (Fig. 93); dorsal dark brown marks on terga 4-7 (Fig. 93) with pale median area on terga 45 , marks on terga 8-9 as on tergum 7 except a lighter reddish-brown, tergum 10 pale with black posterior margin ; black marks at spiracles, tracheae hyaline ; sterna pale except sternum 9 with faint darker brown triangular mark ; posterior margin of sternum 7 as in Fig. 66-67 ; ninth sternum shallowly cleft apically (Fig. 56). Caudal filaments : color and marks as in $0^{7}$ imago.

\section{Mature nymph (in alcohol) (Fig. 97)}

Head : light brown, venter paler, darker brown marks as in $\sigma^{\top}$ imago. Thorax : light brown, venter paler, darker marks as in imagos including black margin of mesoscutellum. Legs : pale, darker brown marks as in $\sigma^{\top}$ imago, except mark at apex of tibiae faded. Abdomen : color and marks as in imagos. Gills (Fig. 153) : membrane translucent gray, tracheae black. Posterolateral spines on abdominal segments 6-9, those on 6-7 
very small (Fig. 156). Caudal filaments pale with darker brown annulations.

Specimens. Holotype o' imago, No. N42 ; allotype ㅇ imago, No. N42 ; paratypes : $10^{\circ}$, No. N37 ; $10^{\circ}$, No. N41 ; 10 ơ, 3 \%, 1 \% subimago, 1 nymph, No. N42 ; 6 nymphs, No. FNK62 ; 3 nymphs, No. FNK66, 2 nymphs, No. FNK68 ; 3 nymphs, No. FNK 79 ; 1 nymph, No. FNK105, 1 nymph, No. FNK111, 2 nymphs, No. FNK120. All types are in alcohol. Association of the nymph and imagos is by abdominal color pattern, markings on the mesoscutellum, and markings on the costal brace of developing wings of mature nymphs. Type depositions : holotype, allotype, and paratypes at FAMU, except : $2 \sigma^{\circ}, 1 \%$ and 2 nymphal paratypes at NMNH and ORSTOM ; $20^{\circ}$ and 2 nymphal paratypes each at CTFT and BPBM. Material from the southern region ( $1 \sigma^{\circ}, 1$ \&, No. N26; 2 young nymphs, No. FNK8) is not included in the type series as markings on the wings and abdomen are faded, especially on the male.

The color pattern on terga 8-9 of $\sigma^{7}$ imagos from the type locality is variable and can be lighter than described. In 9 imagos, the marks on tergum 4 may be heavier, a thin pale median line may be present or absent on terga $1-3$, and the intensity of color on terga $7-9$ varies as in males.

Etymology. orthogonios, Gr., meaning rectangular.

Discussion. Amoa orthogonia can be distinguished from the remaining species of Amoa by characters given in the keys. In addition, the scutellum of the mesothorax of nymphs and adults is pale with a blackishbrown posterior border (Fig. 97). The species is dis- tinct from other species of Amoa and might be considered for subgeneric status.

Biology. Amoa orthogonia occurs throughout New Caledonia, but collection records are rare from all localities. Nymphs were found in streams with water temperatures of $17.1-24.5^{\circ} \mathrm{C}$ and at $46-458 \mathrm{~m}$. Most specimens were collected in streams with water temperatures of $18-19^{\circ} \mathrm{C}$. Nothing is known about the habits of the imagos or nymphs.

\section{References}

Pescador M.L. \& Rasmussen A.K. 1995. - Nymphal abnormalities in Stenacron interpunctatum (Ephemeroptera : Heptageniidae) from the Fenholloway River, Florida : 55-77, in Corkum, L. D. \& J. J. H. Ciborowski (eds), Current Directions in Research on Ephemeroptera. Canadian Scholars Press.

Peters W.L. \& Peters J.G. 1979-1980. — The Leptophlebiidae of New Caledonia (Ephemeroptera). Part II. Systematics. Cah. ORSTOM, sér. Hydrobiol., 13 1-2 :61-82.

Peters W.L. \& Peters J.G. 1981a. - The Leptophlebiidae of New Caledonia (Ephemeroptera). Part III. Systematics. Rev. Hydrobiol. trop. 14 ( $3: 233-243$.

Peters W.L. \& Peters J.G. 1981b. - The Leptophlebiidae of New Caledonia (Ephemeroptera). Part IV. Systematics. Rev. Hydrobiol. trop. 14 ( $3: 245-252$.

Peters W.L., Peters J.G. \& Edmunds G.F., Jr.. 1978. - The Leptophlebiidae of New Caledonia (Ephemeroptera). Part I. Introduction and Systematics. Cah. ORSTOM, Sér . Hydrobiol., 12 (2) : 97-117.

Peters W.L., Peters J.G. \& Edmunds G. F., Jr.. 1990. — The Leptophlebiidae of New Caledonia (Ephemeroptera). Part V. Systematics. Rev. Hydrobiol. trop. 23 (2) :245-252.

Peters W.L., Peters J.G. \& Edmunds G.F., Jr. 1994. — The Leptophlebiidae of New Caledonia (Ephemeroptera). Part VI. Systematics. Rev. Hydrobiol. trop. 1994, 27 (2) : 97-105.

Towns D.T. \& Peters W.L. 1996. - Leptophlebiidae (Insecta : Ephemeroptera). Fauna of New Zealand No. 36. Manaaki Whenua Press, Lincoln, Canterbury, N.Z : 141 p. 
APPENDIX.

Source of Material

\begin{tabular}{|c|c|c|c|c|c|}
\hline Species & Locality & Figure Number & Species & Locality & $\underline{\text { Figure Number }}$ \\
\hline \multirow[t]{8}{*}{ Paraluma cancellata } & N13 & $1-3,35,100,140$ & Amoa subsolana & $\mathrm{N} 21$ & 43,132 \\
\hline & $\mathrm{N} 28$ & $46-48$ & subsolana & N37 & $84-85$ \\
\hline & N40 & 49 & & FNK35 & 147 \\
\hline & $\mathrm{N} 26$ & 50 & & & \\
\hline & FNK4 & 101 & A. subsolana & N26 & $86-87$ \\
\hline & FNK5 & 102 & caerulea & N27 & 96 \\
\hline & FNK94 & 141 & & & \\
\hline & & & A. hebes & N27 & all \\
\hline \multirow[t]{2}{*}{ P. triangularis } & N55 & $94,138-139$ & & & \\
\hline & N13 & all other & A. cressonensis & FNK 110 & all \\
\hline P. gilva & N37 & all & A. orthogonia & N42 & $\begin{array}{l}19-22,31,45,56 \\
66-67,91-93\end{array}$ \\
\hline \multirow{2}{*}{ P. pulla } & $\mathrm{N} 42$ & $5,25-26,38,71-72$ & & FNK66 & $97,153,156$ \\
\hline & FNK88 & 104,135 & & FNK120 & $120-123,133$ \\
\hline \multirow[t]{2}{*}{ P. minuta } & $\begin{array}{l}\text { N51 } \\
\text { N26 }\end{array}$ & $\begin{array}{l}6,40,59,73-74,105 \\
60-61\end{array}$ & Oumas orbis & $\mathrm{N} 42$ & $\begin{array}{l}10-12,27-28,33,41 \\
79-80\end{array}$ \\
\hline & & & & N37 & $54,62-63,77-78$ \\
\hline \multirow[t]{2}{*}{ P. maculata } & N51 & all & & FNK55 & 95 \\
\hline & & & & FNK82 & $128,142-143$ \\
\hline \multirow[t]{2}{*}{ Amoa fronini } & N31 & $\begin{array}{l}13-15,34,42,81-82 \\
149,155\end{array}$ & & FNK84 & $\begin{array}{l}109-112,114,127, \\
129,144-145\end{array}$ \\
\hline & $\begin{array}{r}\text { FNK37 } \\
\text { N33 }\end{array}$ & $\begin{array}{l}154 \\
\text { all other }\end{array}$ & & FNK94 & 113 \\
\hline
\end{tabular}

